\title{
Cannabinoids Accumulation in Hemp (Cannabis sativa L.) Plants under LED Light Spectra and Their Discrete Role as a Stress Marker
}

\author{
Md. Jahirul Islam 1,2 (D), Byeong Ryeol Ryu ${ }^{1}\left(\mathbb{D}\right.$, Md. Obyedul Kalam Azad $^{1}\left(\mathbb{D}\right.$, Md. Hafizur Rahman ${ }^{1}$, \\ Eun Ju Cheong ${ }^{3} \mathbb{D}$, Jung-Dae Lim ${ }^{1,4, * \mathbb{D}}$ and Young-Seok Lim ${ }^{1, * \mathbb{D}}$
}

1 Department of Bio-Health Convergence, College of Biomedical Science, Kangwon National University, Chuncheon 24341, Korea; jahirulislam213@gmail.com (M.J.I.); fbqudfuf0419@naver.com (B.R.R.); azadokalam@gmail.com (M.O.K.A.); hafizknu94@gmail.com (M.H.R.)

2 Physiology and Sugar Chemistry Division, Bangladesh Sugarcrop Research Institute, Ishurdi, Pabna 6620, Bangladesh

3 Division of Forest Science, College of Forest and Environmental Sciences, Kangwon National University, Chuncheon 24341, Korea; ejcheong@kangwon.ac.kr

4 Department of Herbal Medicine Resource, Kangwon National University, Samcheok 25949, Korea

* Correspondence: ijdae@kangwon.ac.kr (J.-D.L.); potatoschool@kangwon.ac.kr (Y.-S.L.); Tel.: +82-33-540-3323 (J.-D.L.); +82-33-250-6474 (Y.-S.L.)

\section{check for} updates

Citation: Islam, M.J.; Ryu, B.R.; Azad, M.O.K.; Rahman, M.H.;

Cheong, E.J.; Lim, J.-D.; Lim, Y.-S. Cannabinoids Accumulation in Hemp (Cannabis sativa L.) Plants under LED Light Spectra and Their Discrete Role as a Stress Marker. Biology 2021, 10, 710. https://doi.org/10.3390 /biology10080710

Academic Editors: Ankush Prasad, Pavel Pospíšil and Dorothea Bartels

Received: 24 April 2021

Accepted: 22 July 2021

Published: 24 July 2021

Publisher's Note: MDPI stays neutral with regard to jurisdictional claims in published maps and institutional affiliations.

Copyright: (C) 2021 by the authors Licensee MDPI, Basel, Switzerland. This article is an open access article distributed under the terms and conditions of the Creative Commons Attribution (CC BY) license (https:// creativecommons.org/licenses/by/ $4.0 /)$.
Simple Summary: Cannabinoids accumulation in the hemp plant greatly depends on light quality under a controlled growing system. Sativa-type hemp plant (enriched with THC) increased CBD accumulation under some controlled light combinations. Green light has a significant role in CBD and CBDA synthesis, where FR and UV-A (along with green) play a positive and negative role in this process, respectively. Earlier, cannabinoids were identified as stress markers, but it was unclear which compound/compounds are directly involved with the light stress environment as stress markers in the hemp plant. In our study, THCA showed a significant role as a stress marker followed by CBDA. On the other hand, THC and CBD showed a negligible response as stress response compounds to such conditions.

Abstract: Hemp adaptability through physiological and biochemical changes was studied under 10 LED light spectra and natural light in a controlled aeroponic system. Light treatments were imposed on 25 days aged seedlings for $16 \mathrm{~h}$ daily $\left(300 \mu \mathrm{mol} \mathrm{m}^{-2} \mathrm{~s}^{-1}\right)$ for 20 days. Plant accumulated highest Cannabidiol (CBD) in $\mathrm{R}_{7}: \mathrm{B}_{2}: \mathrm{G}_{1}$ light treatment, with relatively higher photosynthetic rate and lower reactive oxygen species, total phenol content, total flavonoid content, DPPH radical scavenging capacity, and antioxidant enzymatic activities. Tetrahydrocannabinol (THC) also accumulated at a higher level in white, $\mathrm{R}_{8}: \mathrm{B}_{2}$, and $\mathrm{R}_{7}: \mathrm{B}_{2}: \mathrm{G}_{1}$ light with less evidence of stress-modulated substances. These results indicated that CBD and THC have no or little relation with light-mediated abiotic stress in hemp plants. On the contrary, Tetrahydrocannabinolic acid (THCA) was accumulated higher in $\mathrm{R}_{6}: \mathrm{B}_{2}: \mathrm{G}_{1}: \mathrm{FR}_{1}$ and $\mathrm{R}_{5}: \mathrm{B}_{2}: \mathrm{W}_{2}: \mathrm{FR}_{1}$ light treatment along with lower photosynthetic rate and higher reactive oxygen species, total phenol content, total flavonoid content, DPPH radical scavenging capacity, and antioxidant enzymatic activities. However, Cannabidiolic acid (CBDA) was accumulated higher in $\mathrm{R}_{6}: \mathrm{B}_{2}: \mathrm{G}_{1}: \mathrm{FR}_{1}$ light treatment with higher stress-modulated substances and lower physiological traits. CBDA was also accumulated higher in $R_{8}: B_{2}$ and $R_{7}: B_{2}: G_{1}$ light treatments with less evidence of stress-modulated substances. Besides, Greenlight influenced CBD and CBDA synthesis where FR and UV-A (along with green) play a positive and negative role in this process. Overall, the results indicated that the treatment $R_{7}: B_{2}: G_{1}$ enhanced the medicinal cannabinoids most, and the role of THCA as a stress marker is more decisive in the hemp plant than in other cannabinoids under attributed light-mediated stress.

Keywords: hemp; light spectra; light stress; photosynthetic activities; antioxidant enzymes; antioxidant; cannabinoids and stress markers 


\section{Introduction}

Light is the primary source of energy for plant growth and development through photosynthesis. This growth and developmental process depend on light spectral quality, intensity, compositions, duration, and direction [1]. A small irradiance of light can bring changes in several compositions in growing plants [2]. These processes come through light interaction with species and cultivars, which mainly depend on its irradiation, enhancing stressful or non-stressful events for plants [3]. Despite energy sources for photosynthesis, light can simultaneously act as a stress factor as plant response to light mainly depends on the lighting environment, genotypes, cultivation practices, etc. [4]. Excess light (irrespective of temperature effect) increases evaporation and photoinhibition, resulting in dehydration in leaf tissue, causing reduced photosynthetic production [5].

Plants respond differently to each spectral band of light. Plants use the wavelength of red light to accumulate carbohydrates and nutrients [6,7], red and blue for electron excitation in the photosynthesis process $[1,8]$ and, blue and UV to synthesize carotenoids and anthocyanins $[9,10]$. Evidence showed that high intensities of UV-B radiation cause stress to plant by inducing DNA damage, photoinhibition, lipid peroxidation, and finally, growth retardation [11]. When plants are exposed to such light intensities or any abiotic stress condition, the demand for metabolic processes in carbon fixation increases for energy supply and reduces power by involving photosystems and electron transport chains $[12,13]$. This asymmetry generates reactive oxygen species (ROS), which have both signaling and toxic (oxidative damage by inducing lipid peroxidation) effects on cells $[1,14]$. Light intensity below the compensation point also will result in a net loss of photosynthetic products, and more light after saturation point has no or negative effect on photosynthesis [7,15].

Bioactive compounds are collectively known as primary and secondary metabolites, which gave aroma, color, taste even provide resistance against external biotic and abiotic stress [16]. Evidence proved that different forms of external stress help plants produce bioactive compounds [17-22]. Previous studies suggested that the R:FR ratio, the blue and UV light photoreceptors (CRYs, PHOTs, and UVR8), can alter signaling pathways. These changes may affect phytohormone-mediated regulation of growth, development, physio-biochemical pathways, finally, plant root architecture [23-25], which may create partial water stress to plant.

It was reported that despite the negative effect on quantum yield, plants attained a higher photosynthetic rate and biomass accumulation under supplemental UV-A radiation. This higher photosynthetic rate was due to an increase of stomatal conductance (gs) instead of the ratio of intracellular to ambient $\mathrm{CO}_{2}$ content (Ci/Ca) [26]. Besides these, ultraviolet light has a crucial role in plant response to several morphological, physiological, and secondary metabolites production, which are combinedly termed as plant photomorphogenic response [27-30]. These photomorphogenic responses mainly controlled by UVR8 by regulating gene expression relate to hypocotyl elongation inhibition, DNA repair, antioxidative defense, and phenolic compounds production [31]. On the other hand, far-red (710-850 nm) may have an essential role in photosynthetic purposes in leaves [32]. A high or low $\mathrm{R}$ and FR light ratio change the mode of action in phytochromes, converting the Pr into Pfr, or vice versa [20]. This conversion may bring changes in gene expression related to photomorphogenesis [33-35]. However, the role of UV-A and FR with the combination of other spectral bands relate to plant physiology, and morphological changes remain poorly understood.

Hemp is an annual herb belongs to the Cannabaceae family has been exploited for medicinal purposes for more than 10,000 years [36]. Living hemp plants contain cannabinoids as carboxylic acid like THCA and CBDA that decarboxylate during storage and heating transform to neutral cannabinoids such as THC and CBD [37-40]. Although secondary metabolites in cannabis are mostly controlled by selecting genotypes and their phenotypic characteristics; however, some horticultural techniques, including photoperiod, lighting intensity, and quality, can change among them [37,41-43]. Earlier in a study, the 
increment of THC in cannabis was described when it was treated under controlled UV-B radiation [41]. Ning et al. showed that UV-A and UV-B could increase secondary metabolites in Lonicera japonica medicinal plants [44]. For this reason, the plant treated with low dose UV mediated stress is crucial from a biotechnological and pharmaceutical point of view to increase valuable compounds [45]. Previous studies revealed that under long-time UV treatment, all types of cannabinoids did not respond equally [41,46]. It is also essential to find out the LED combination that can manipulate different targeted cannabinoids compounds by bringing in a metabolic system change in hemp plants. Besides, it is not clear which cannabinoids are directly involved with a light stress environment identified as stress markers in the hemp plant. Therefore, the objectives of the study were to determine the suitable LED combination for the higher accumulation of medicinal cannabinoids and select the stress markers of cannabis plants under light-mediated stress conditions.

\section{Materials and Methods}

\subsection{Experimental Design and Treatment}

Hemp seeds (Cannabis sativa L. strain India) were sown in sixteen cells plug tray $(27 \mathrm{~cm} \times 27 \mathrm{~cm} \times 6 \mathrm{~cm}$ ) filled with commercial soil mixture (Bio-soil No. 1, Heungnong Agricultural Materials Mart, Korea) in a glasshouse. Before sowing, the seeds were sterilized $\left[70 \%(v / v)\right.$ ethanol, $0.1 \%(w / v) \mathrm{HgCl}_{2}$ and $0.2 \%(w / v)$ thiram] and soaked in water for $24 \mathrm{~h}$ at room temperature to facilitate the germination. The environmental conditions such as temperature, relative humidity $(\mathrm{RH})$, and photoperiod were recorded at $30 / 25^{\circ} \mathrm{C}$ (day/night), $60-70 \%$, and $12 \mathrm{~h}$, respectively. The seedlings were irrigated daily using tap water to the field capacity level. After three weeks, the seedlings were transferred/transplanted to the steel made chamber $(80 \mathrm{~cm} \times 60 \mathrm{~cm} \times 80 \mathrm{~cm})$ to adjust with the nutrient solution. After one week of adjustment, the plants were subjected to treatment with different LED light (Bisol LED light Co., Seoul, Korea) combination (Figure 1; Table 1). The photosynthetic photon flux density (PPFD), photoperiod, and temperature of the chamber were $300 \mu \mathrm{mol} \mathrm{m}{ }^{-2} \mathrm{~s}^{-1}, 16 \mathrm{~h}(6.00 \mathrm{AM}$ to $10.00 \mathrm{PM})$, and 23 to $27^{\circ} \mathrm{C}$, respectively. The PPFD was checked and adjusted at the top leaf-level every other day. The plant chamber was designed for an aeroponic system where nutrient formulated water (Table 2) was sprayed to the plant root zone for twenty seconds every two minutes. After 20 days of LED treatment, the youngest completely formed leaves were collected as samples from several randomly selected plants as biological replications subjected to further analysis.

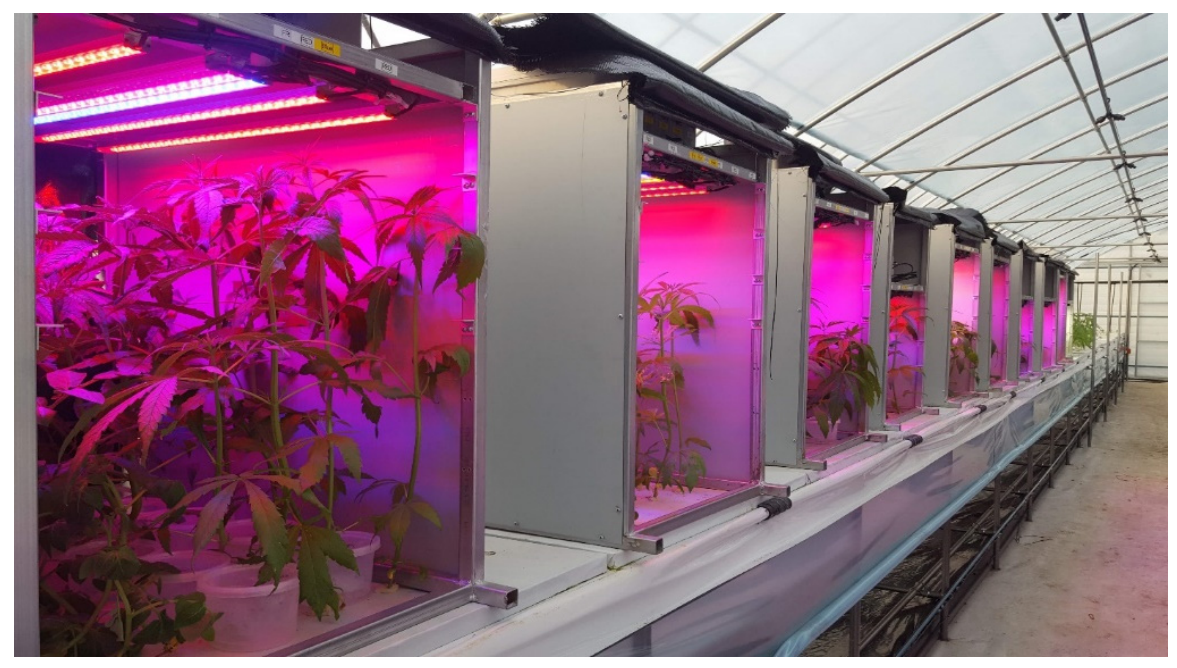

Figure 1. Hemp plant under treatment in steel made chamber $(80 \mathrm{~cm} \times 60 \mathrm{~cm} \times 80 \mathrm{~cm})$ equipped with different LED light. Here and subsequent models: L1, Natural light; L2, White; $L 3, \mathrm{R}_{8}: \mathrm{B}_{2} ; \mathrm{L4}, \mathrm{R}_{7}: \mathrm{B}_{2}: \mathrm{G}_{1}$; L5, $\mathrm{R}_{7}: \mathrm{B}_{2}: \mathrm{FR}_{1} ; \mathrm{L} 6, \mathrm{R}_{6}: \mathrm{B}_{2}: \mathrm{G}_{1}: \mathrm{FR}_{1} ; \mathrm{L} 7, \mathrm{R}_{5}: \mathrm{B}_{2}: \mathrm{W}_{2}: \mathrm{FR}_{1} ; \mathrm{L} 8, \mathrm{R}_{5}: \mathrm{B}_{2}: \mathrm{G}_{1}: \mathrm{FR}_{1}: \mathrm{UV}_{1} ; \mathrm{L} 9, \mathrm{R}_{6}: \mathrm{B}_{2}: \mathrm{FR}_{1}: \mathrm{UV}_{1} ; \mathrm{L} 10$, $\mathrm{R}_{4}: \mathrm{B}_{2}: \mathrm{W}_{2}: \mathrm{FR}_{1}: \mathrm{UV}_{1} ; \mathrm{L} 11, \mathrm{R}_{2}: \mathrm{B}_{2}: \mathrm{G}_{2}: \mathrm{W}_{2}: \mathrm{FR}_{1}: \mathrm{UV}_{1}$. All treatments used a photosynthetic photon flux density of $300 \mu \mathrm{mol} \mathrm{m}$ boldmath-2 $\mathrm{s}^{\text {boldmath }-1}$. 
Table 1. LED light composition.

\begin{tabular}{|c|c|c|c|}
\hline Spectrum Combinations & Ratio (\%) & Intensity $\left(\mu \mathrm{mol} \mathrm{m} \mathrm{m}^{-2} \mathrm{~s}^{-1}\right)$ & Code Name \\
\hline Natural light & - & - & L1 \\
\hline White & 100 & 300 & L2 \\
\hline $\mathrm{R}+\mathrm{B}$ & $80: 20$ & 300 & L3 \\
\hline $\mathrm{R}+\mathrm{B}+\mathrm{G}$ & $70: 20: 10$ & 300 & L4 \\
\hline $\mathrm{R}+\mathrm{B}+\mathrm{FR}$ & $70: 20: 10$ & 300 & L5 \\
\hline$R+B+G+F R$ & 60:20:10:10 & 300 & L6 \\
\hline $\mathrm{R}+\mathrm{B}+\mathrm{W}+\mathrm{FR}$ & 50:20:20:10 & 300 & L7 \\
\hline $\mathrm{R}+\mathrm{B}+\mathrm{G}+\mathrm{FR}+\mathrm{UV}$ & 50:20:10:10:10 & 300 & L8 \\
\hline $\mathrm{R}+\mathrm{B}+\mathrm{FR}+\mathrm{UV}$ & $60: 20: 10: 10$ & 300 & L9 \\
\hline $\mathrm{R}+\mathrm{B}+\mathrm{W}+\mathrm{FR}+\mathrm{UV}$ & $40: 20: 20: 10: 10$ & 300 & L10 \\
\hline $\mathrm{R}+\mathrm{B}+\mathrm{G}+\mathrm{W}+\mathrm{FR}+\mathrm{UV}$ & $20: 20: 20: 20: 10: 10$ & 300 & L11 \\
\hline
\end{tabular}

Table 2. Nutrient solution.

\begin{tabular}{ccc}
\hline Chemical Name & A Tank $(50 \mathrm{~L}){ }^{*}$ & B Tank $(50 \mathrm{~L})$ \\
\hline $\mathrm{Ca}\left(\mathrm{NO}_{3}\right)$ & $1.5 \mathrm{~kg}$ & \\
$\mathrm{KNO}_{3}$ & $3.79 \mathrm{~kg}$ & $3.79 \mathrm{~kg}$ \\
$\left(\mathrm{NH}_{4}\right)_{2} \mathrm{HPO}_{4}$ & & $1.6 \mathrm{~kg}$ \\
$\mathrm{MgSO}_{4}$ & & $4.3 \mathrm{~kg}$ \\
$\mathrm{~K}_{2} \mathrm{SO}_{4}$ & $460 \mathrm{~g}$ & \\
$\mathrm{Fe}_{-\mathrm{EDTA}}$ & & \\
$\mathrm{MnSO}_{4}$ & & $30.8 \mathrm{~g}$ \\
$\mathrm{H}_{3} \mathrm{BO}_{3}$ & & $57.2 \mathrm{~g}$ \\
$\mathrm{ZnSO}_{4}$ & $3.6 \mathrm{~g}$ \\
$\mathrm{CuSO}_{4}$ & $1.3 \mathrm{~g}$ \\
$\left(\mathrm{NH}_{4}\right)_{6} \mathrm{Mo}_{7} \mathrm{O}_{24} \cdot 4 \mathrm{H}_{2} \mathrm{O}$ & $0.4 \mathrm{~g}$ \\
\hline
\end{tabular}

* Solution of Tank A and Tank B were subjected to mixed to maintain a E.C. range between 1.2-1.7 (ds $\left.\mathrm{m}^{-2}\right)$.

\subsection{Leaf Gas Exchange Measurement}

The net photosynthetic rate $\left(\mathrm{A}, \mu \mathrm{mol} \mathrm{m} \mathrm{m}^{-2} \mathrm{~s}^{-1}\right)$, transpiration rate $\left(\mathrm{E}, \mathrm{mmol} \mathrm{m} \mathrm{m}^{-2} \mathrm{~s}^{-1}\right)$, stomatal conductance (gs, $\mathrm{mmol} \mathrm{m}^{-2} \mathrm{~s}^{-1}$ ) were measured on well-developed leaves (3rd node from the top) of six plants under each treatment using an LCpro gas analyzer (ADC BioScientific Ltd., Hoddesdon, Herts EN11 ONT, UK). The level of A, gs, E, and WUE was measured at the ambient environmental condition. The measurements of gas exchange were carried out at the mid-day between 10.00 AM and 3.00 PM. The photosynthetic water use efficiency (WUE) was calculated as the ratio A/E.

\subsection{Measuring Malondialdehyde and $\mathrm{H}_{2} \mathrm{O}_{2}$ Concentration}

Malondialdehyde (MDA) was measured to determine the lipid peroxidation in the hemp leaves. For MDA assay, the freeze-dried leaf samples $(25 \mathrm{mg})$ were ground in $5 \mathrm{~mL}$ of $0.1 \%$ trichloroacetic acid and centrifuged at $10,000 \times \mathrm{g}$ for $10 \mathrm{~min}$ at $4{ }^{\circ} \mathrm{C}$. A $4 \mathrm{~mL}$ of $20 \%$ trichloroacetic acid (TCA) containing $0.5 \%$ thiobarbituric acid was added to $1 \mathrm{~mL}$ of supernatant. The mixture was heated at $95{ }^{\circ} \mathrm{C}$ for $30 \mathrm{~min}$, followed by cooled quickly on an ice bath. The resulting mixture was centrifuged again at $5000 \mathrm{rpm}$ for $15 \mathrm{~min}$, and the absorbance was taken at $532 \mathrm{~nm}$ and $600 \mathrm{~nm}$. An extinction coefficient of $155 \mathrm{mM}^{-1} \mathrm{~cm}^{-1}$ was used to calculate the MDA concentration [47].

The $\mathrm{H}_{2} \mathrm{O}_{2}$ content was estimated according to the method developed by Singh et al. [48]. $25 \mathrm{mg}$ of freeze-dried leaves were extracted in $5 \mathrm{~mL}$ of $0.1 \%(w / v)$ TCA and centrifuged at $12,000 \times g$ for $15 \mathrm{~min}$ in a refrigerated centrifuge. Then $0.5 \mathrm{~mL}$ of the super-

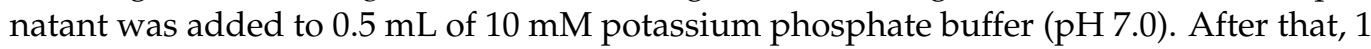
$\mathrm{mL}$ of $1 \mathrm{M} \mathrm{KI}$ was added to the mixture and placed in a dark place $(1 \mathrm{~h})$ for incubation. The absorbance was measured at $390 \mathrm{~nm}$, where a standard $\mathrm{H}_{2} \mathrm{O}_{2}$ curve was prepared to calculate the concentration of $\mathrm{H}_{2} \mathrm{O}_{2}$ in the sample. 


\subsection{Activities of Antioxidant Enzymes}

For the analysis of antioxidant enzymes, leaf samples were collected and immersed immediately in liquid nitrogen and stored at $-80{ }^{\circ} \mathrm{C}$ until use. A $200 \mathrm{mg}$ sample was homogenized in $5 \mathrm{~mL}$ of $50 \mathrm{mM}$ sodium phosphate buffer solution ( $\mathrm{pH} 7.8$ ) using a prechilled mortar and pestle, then centrifuged at $15,000 \times g$ for 20 min at $4{ }^{\circ} \mathrm{C}$. After collecting the supernatant, the enzyme extract was stored at $4{ }^{\circ} \mathrm{C}$ for analysis [49].

The superoxide dismutase activity (SOD; EC 1.15.1.1) was estimated by the method described earlier [50]. The reaction mixture for estimating SOD contained $50 \mathrm{mM}$ sodium phosphate buffer with $0.1 \mathrm{mM}$ EDTA, $12 \mathrm{mM}$ methionine, $75 \mu \mathrm{M} \mathrm{NBT}$, and $50 \mathrm{mM} \mathrm{Na}_{2} \mathrm{CO}_{3}$. Then, a $100 \mu \mathrm{L}$ enzyme extract or $100 \mu \mathrm{L}$ buffer was used in the sample or blank, respectively. After that, $300 \mu \mathrm{L}$ of $0.1 \mathrm{mM}$ Riboflavin was added to the reaction mixture to make $2 \mathrm{~mL}$ of the final volume. The tubes were shaken and irradiated under the fluorescent light $(15 \mathrm{~W})$ for $15 \mathrm{~min}$. The absorbance was taken at $560 \mathrm{~nm}$ by a spectrophotometer. From the result, $50 \%$ inhibition of NBT reduction was considered as one unit of the enzyme [51].

The activities of Guaiacol peroxidase (POD; EC 1.11.1.7) and catalase (CAT; EC 1.11.1.6) were assayed by the method of Zhang [52]. For POD assay, a $3 \mathrm{~mL}$ reaction mixture contained $100 \mu \mathrm{L}$ enzyme extract, $100 \mu \mathrm{L}$ guaiacol $(1.5 \%, v / v), 100 \mu \mathrm{L} \mathrm{H}_{2} \mathrm{O}_{2}(300 \mathrm{mM})$, and $2.7 \mathrm{~mL} 25 \mathrm{mM}$ sodium phosphate buffer with $2 \mathrm{mM}$ EDTA ( $\mathrm{pH}$ 7.0). The absorbance was measured by a spectrophotometer at $470 \mathrm{~nm}\left(\epsilon=26.6 \mathrm{mM} \mathrm{cm}^{-1}\right)$. On the other hand, The assay mixture for CAT contained $100 \mu \mathrm{L}$ of enzyme extract, $100 \mu \mathrm{L}$ of $\mathrm{H}_{2} \mathrm{O}_{2}(300 \mathrm{mM})$, and $2.8 \mathrm{~mL}$ of $50 \mathrm{mM}$ phosphate buffer with $2 \mathrm{mM}$ EDTA ( $\mathrm{pH}$ 7.0). The decreased absorbance rate was measured at $240 \mathrm{~nm}\left(\epsilon=39.4 \mathrm{mM} \mathrm{cm}^{-1}\right)$.

The Ascorbate peroxidase (APX; EC 1.11.1.11) activity was assayed by the method of Nakano and Asada [53]. The reaction mixture $(3 \mathrm{~mL})$ contained $25 \mu \mathrm{L}$ enzyme extract, $100 \mu \mathrm{L}$ ascorbate $(7.5 \mathrm{mM}), 100 \mu \mathrm{L} \mathrm{H}_{2} \mathrm{O}_{2}(300 \mathrm{mM})$, and $2.775 \mathrm{~mL}$ of $25 \mathrm{mM}$ sodium phosphate buffer (2 mM EDTA, $\mathrm{pH} 7.0)$. The decrease of absorbance at $290 \mathrm{~nm}$ was considered to calculate APX activity using an extinction coefficient of $2.8 \mathrm{mM} \mathrm{cm}^{-1}$.

\subsection{Estimation of Total Phenolic Content (TPC), Total Flavonoid Content (TFC), and Antioxidant Capacity}

$25 \mathrm{mg}$ of freeze-dried leaf samples were homogenized in $10 \mathrm{~mL}$ of ethanol $(80 \%, v / v$ in water) followed by sonication at $35{ }^{\circ} \mathrm{C}$ for $60 \mathrm{~min}$. Then, the extracts were filtered (Advantech 5B filter paper, Tokoyo Roshi Kaisha Ltd., Saitama, Japan) and preserved at $4{ }^{\circ} \mathrm{C}$ in a refrigerator for further analysis).

The total phenolic content (TPC) of the sample was estimated by the Folin-Ciocalteu method [54]. The reaction mixture consisted of a $1 \mathrm{~mL}$ sample, $200 \mu \mathrm{L}$ phenol reagent $(1 \mathrm{~N})$, and $1.8 \mathrm{~mL}$ water. The mixture was vortexed and wait for $3 \mathrm{~min}$, and then $400 \mu \mathrm{L}$ of $\mathrm{Na}_{2} \mathrm{CO}_{3}(10 \%, v / v$ in water) was added. After that, the mixture was diluted by adding $600 \mu \mathrm{L}$ of distilled water to get the final volume $(4 \mathrm{~mL})$ and left for $1 \mathrm{~h}$ incubation at room temperature. The absorbance was taken at $725 \mathrm{~nm}$ spectrophotometrically, and TPC was calculated based on a standard calibration curve of Gallic acid and expressed as $\mu \mathrm{g} \mathrm{g}^{-1}$ dry weight.

The total flavonoid content (TFC) was determined by the method of Ghimeray et al. [55]. In the assay, $500 \mu \mathrm{L}$ of the extract was mixed with $100 \mu \mathrm{L}$ of $\mathrm{Al}\left(\mathrm{NO}_{3}\right)_{3}(10 \%$, $w / v)$ and $100 \mu \mathrm{L}$ of potassium acetate $(1 \mathrm{M})$ solution. After that $3.3 \mathrm{~mL}$ of distilled water was added to the mixture to adjust the final volume up to $4 \mathrm{~mL}$. The reaction mixture was vortexed and incubated at room temperature for $40 \mathrm{~min}$. Then the absorbance was measured at $415 \mathrm{~nm}$ by a UV-Vis spectrophotometer, and the TFC was calculated as $\mathrm{mg} / \mathrm{g}$ of Quercetin equivalent on a dry weight basis.

The free radical scavenging activity of cannabis leaf was estimated by the method of Braca et al. [56]. Briefly, DPPH (2,2-diphenyl-1 picrylhydrazyl) powder (5.914 mg) was dissolved in methanol $(100 \mathrm{~mL})$ to prepare a stock solution, and the absorbance range was maintained between 1.1 and 1.3 by a spectrophotometer. Then $1 \mathrm{~mL}$ extract was mixed with $3 \mathrm{~mL}$ of DPPH in test tubes followed by vortexed and allowed to stand for $30 \mathrm{~min}$ at room 
temperature in the dark. The distilled water was used instead of the plant extract to prepare the blank sample. The absorbance was taken at $517 \mathrm{~nm}$ where the scavenging capacity of the samples was calculated by the formula given below, and results were expressed as a percentage $(\%)$ :

$$
\text { Inhibition }(\%)=[(\text { blank sample }- \text { extract sample }) / \text { blank sample }] \times 100
$$

\subsection{Determination of Tetrahydrocannabinol (THC), Tetrahydrocannabinolic Acid (THCA), Cannabidiol (CBD), and Cannabidiolic Acid (CBDA)}

The freeze-dried (100 mg) leaf sample was dissolved in $5 \mathrm{~mL}$ of methanol (100\%) and sonicated at room temperature for $20 \mathrm{~min}$. After filtration through a syringe filter $\left(0.45 \mu \mathrm{M}\right.$, Millipore, Bedford, MA, USA), the solution was kept in a refrigerator at $4{ }^{\circ} \mathrm{C}$. The HPLC system (Shimadzu LC-20 AT, Shimadzu Co., Ltd., Kyoto, Japan) with a UVVIS detector and a reverse phase Zorbax SB-C18 column $(4.6 \mathrm{~mm} \times 100 \mathrm{~mm}, 3.5 \mu \mathrm{m}$, Agilent Technologies, Inc., Santa Clara, CA, USA) was used. The mobile phase was 70\% acetonitrile containing $0.1 \%$ phosphoric acid with isocratic elution mode. The retention times of standard CBDA, CBD, $\triangle 9$-THC, and $\triangle 9$-THCA were 3.60, 4.34, 9.60, and $13.00 \mathrm{~min}$, respectively (Supplementary Figure S1). A $10 \mu \mathrm{L}$ sample was injected where the flow rate and oven temperature was $1.5 \mathrm{~mL} \mathrm{~min}^{-1}$ and $27^{\circ} \mathrm{C}$, respectively. The detection wavelength was used $275 \mathrm{~nm}$ with three biological replications.

\subsection{Statistical Analysis}

All results were expressed as mean \pm SE (standard error). The one-way analysis of variance was performed using Statistix 10 (Tallahassee, FL 32312, USA) following Complete Randomized Design (CRD). Different letters indicate the statistically significant differences between treatments at $p<0.05$, according to the least significant differences (LSD). The heatmap and clustering analysis were prepared by MetaboAnalyst 4.0 (www.metaboanalyst.ca, accessed on 19 July 2021) [57], where samples were normalized by sum, and auto-scaling features were applied. The hierarchical cluster analysis was conducted using the Euclidean distance metric (average linking clustering). The principal component analysis (PCA) was carried out using OriginLab 10.0 software (OriginLab, Northampton, MA, USA). The correlation test was done by SPSS statistical software package (Ver. 23.0, SPSS Inc., Chicago, IL, USA).

\section{Results and Discussion}

\subsection{Effect of LED on Photosynthetic Gas Exchange}

Photosynthetic parameters varied concerning different light treatments (Figure 2). In the current study, photosynthetic rate, transpiration rate, stomatal conductance and water use efficiency ranged from $0.397-6.23 \mu \mathrm{mol} \mathrm{m} \mathrm{m}^{-2} \mathrm{~s}^{-1}, 0.587-3.942 \mathrm{~mol} \mathrm{~m}^{-2} \mathrm{~s}^{-1}$, $0.023-0.1833 \mathrm{~mol} \mathrm{~m}^{-2} \mathrm{~s}^{-1}$ and $0.101-4.647 \mu \mathrm{mol} \mathrm{mol} \mathrm{m} \mathrm{m}^{-2} \mathrm{~s}^{-1}$, respectively. The higher photosynthetic rate was observed in L4, while the transpiration rate and stomatal conductance were higher in L8 and L2 light treatments. On the other hand, higher water use efficiency was recorded in L11 treatment. 


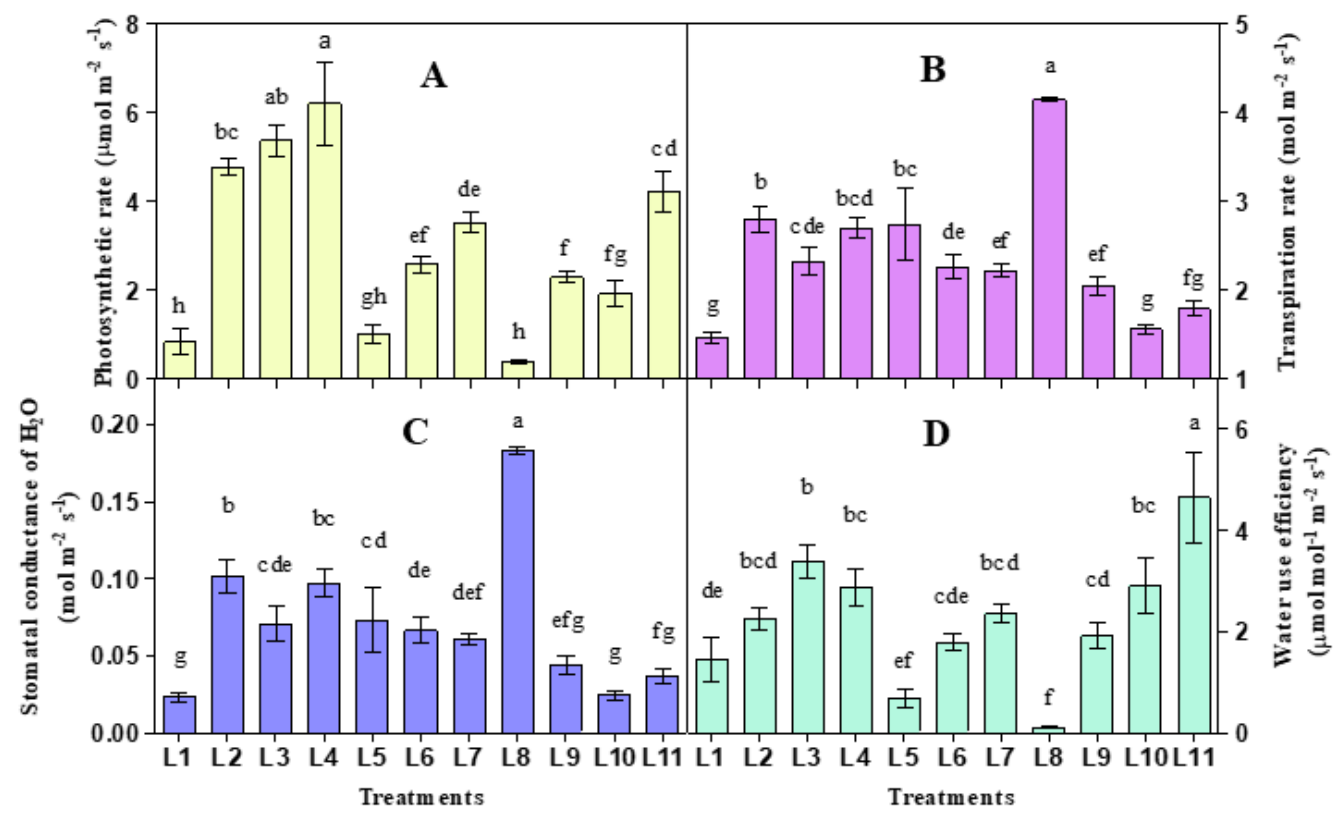

Figure 2. Effect of 20 days exposure to different LED spectra on photosynthetic rate (A), Transpiration rate (B), Stomatal conductance $(\mathbf{C})$ and Water use efficiency (D) of hemp seedlings. Here and subsequent figures: L1, Natural light; L2, White; $\mathrm{L} 3, \mathrm{R}_{8}: \mathrm{B}_{2} ; \mathrm{L} 4, \mathrm{R}_{7}: \mathrm{B}_{2}: \mathrm{G}_{1} ; \mathrm{L} 5, \mathrm{R}_{7}: \mathrm{B}_{2}: \mathrm{FR}_{1} ; \mathrm{L6}$, $\mathrm{R}_{6}: \mathrm{B}_{2}: \mathrm{G}_{1}: \mathrm{FR}_{1} ; \mathrm{L7}, \mathrm{R}_{5}: \mathrm{B}_{2}: \mathrm{W}_{2}: \mathrm{FR}_{1} ; \mathrm{L} 8, \mathrm{R}_{5}: \mathrm{B}_{2}: \mathrm{G}_{1}: \mathrm{FR}_{1}: \mathrm{UV}_{1} ; \mathrm{L} 9, \mathrm{R}_{6}: \mathrm{B}_{2}: \mathrm{FR}_{1}: \mathrm{UV}_{1} ; \mathrm{L} 10, \mathrm{R}_{4}: \mathrm{B}_{2}: \mathrm{W}_{2}: \mathrm{FR}_{1}: \mathrm{UV}_{1}$; L11, $R_{2}: B_{2}: G_{2}: W_{2}: F_{1}: U_{1}$. All treatments used a photosynthetic photon flux density of $300 \mu \mathrm{mol} \mathrm{m} \mathrm{m}^{-2} \mathrm{~s}^{-1}$. Vertical bars indicate mean $\pm \mathrm{SE}$ of six replicates. Different letters indicate significant differences at $p<0.05$.

Photosynthesis can be affected by the stomatal density, distribution, and opening status as it regulates the diffusion of water vapor and the uptake of carbon dioxide in plants. Besides, many factors can influence stomatal behavior, including light, $\mathrm{CO}_{2}$ concentration, and temperature [58]. Some previous studies suggested that light intensity can enhance stomatal conductance in plants [59-61]. Simultaneously, both lower and excessive light can reduce the photosynthetic rate and stomatal conductance [61]. It has also been known that the photosynthetic rate depends on chlorophyll content, and it can be affected by any change in it $[62,63]$. Our study also presented a similar result as under the treatments L1, L5, L6, L7, L8, and L9 plants attain lower chlorophyll content and lower photosynthetic rate. We also observe a similar pattern of results between photosynthesis and water use efficiency and stomatal conductance and transpiration rate.

Both photosynthetic rate and water use efficiency were increased under all light treatments except L5 and L8. On the other hand, transpiration and stomatal conductance significantly increased under all light spectra compared to natural light, except L9, L10 and L11. Plant attained a higher photosynthetic rate and water use efficiency and lower transpiration rate and stomatal conductance under L3, L4, and L11. On the other hand, photosynthetic rate and water use efficiency, and higher transpiration rate and stomatal conductance were recorded lower in L5 and L8 treatments.

\subsection{Influence of LED on Lipid Peroxidation and Hydrogen Peroxide}

Both malondialdehyde (MDA) and $\mathrm{H}_{2} \mathrm{O}_{2}$ level were considerably influenced by different light treatments (Figure 3). Higher MDA was recorded in L6, followed by L1, L5, and L8, while lower MDA was observed in L2, L3, and L4 treatments. On the other hand, plants accumulated higher $\mathrm{H}_{2} \mathrm{O}_{2}$ in L7, followed by L6, L5, L2, and L9, while lower $\mathrm{H}_{2} \mathrm{O}_{2}$ was observed in L8 and L11 treatments. 


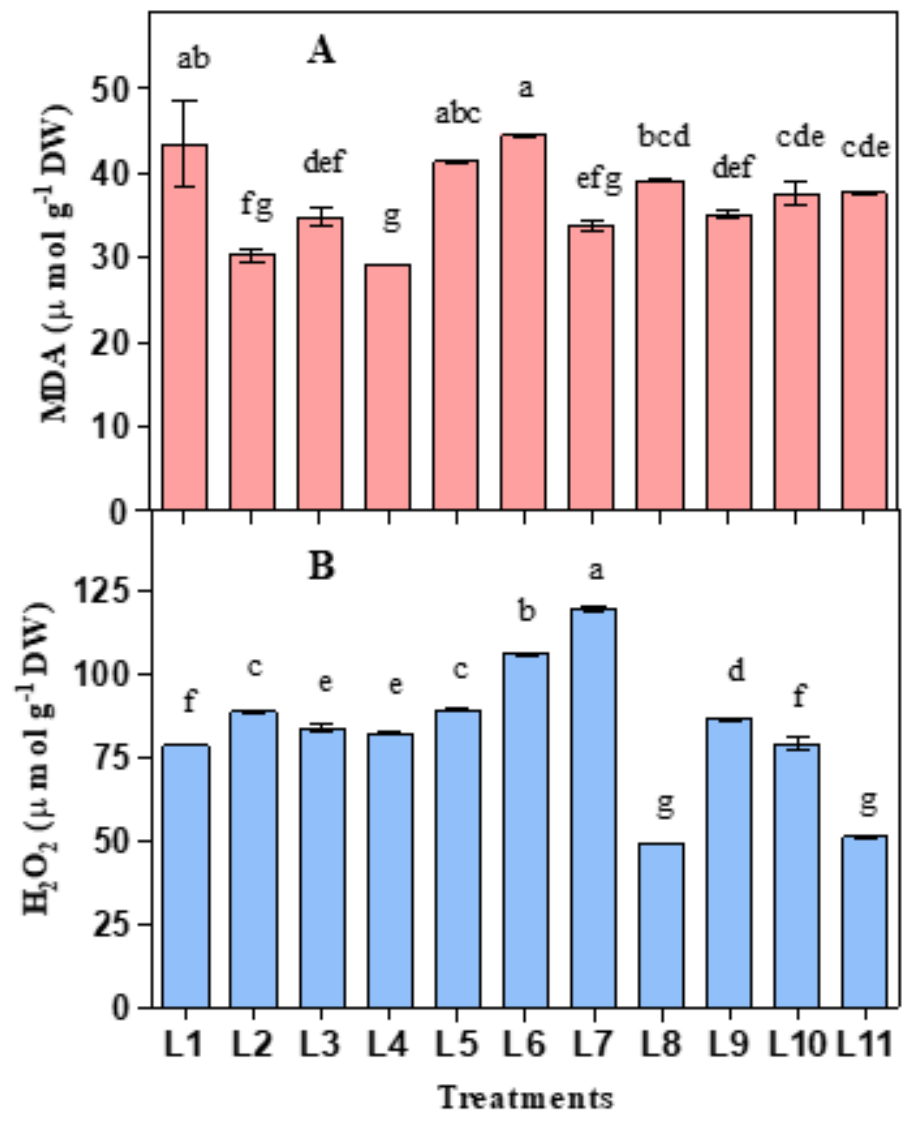

Figure 3. Effect of 20 days exposure to different LED spectra on Lipid peroxidation (MDA) (A) and $\mathrm{H}_{2} \mathrm{O}_{2}$ (B) of hemp seedlings. Here and subsequent figures: L1, Natural light; L2, White; L3, $\mathrm{R}_{8}: \mathrm{B}_{2} ; \mathrm{L} 4, \mathrm{R}_{7}: \mathrm{B}_{2}: \mathrm{G}_{1} ; \mathrm{L} 5, \mathrm{R}_{7}: \mathrm{B}_{2}: \mathrm{FR}_{1} ; \mathrm{L} 6, \mathrm{R}_{6}: \mathrm{B}_{2}: \mathrm{G}_{1}: \mathrm{FR}_{1} ; \mathrm{L} 7, \mathrm{R}_{5}: \mathrm{B}_{2}: \mathrm{W}_{2}: \mathrm{FR}_{1} ; \mathrm{L} 8, \mathrm{R}_{5}: \mathrm{B}_{2}: \mathrm{G}_{1}: \mathrm{FR}_{1}: \mathrm{UV}_{1}$; L9, $\mathrm{R}_{6}: \mathrm{B}_{2}: \mathrm{FR}_{1}: \mathrm{UV}_{1} ; \mathrm{L} 10, \mathrm{R}_{4}: \mathrm{B}_{2}: \mathrm{W}_{2}: \mathrm{FR}_{1}: \mathrm{UV}_{1} ; \mathrm{L11}, \mathrm{R}_{2}: \mathrm{B}_{2}: \mathrm{G}_{2}: \mathrm{W}_{2}: \mathrm{FR}_{1}: \mathrm{UV}_{1}$. All treatments used a photosynthetic photon flux density of $300 \mu \mathrm{mol} \mathrm{m} \mathrm{m}^{-2} \mathrm{~s}^{-1}$. Vertical bars indicate mean $\pm \mathrm{SE}$ of four replicates. Different letters indicate significant differences at $p<0.05$.

In the presence of light, chloroplasts and peroxisomes act as leading ROS producers in plants [64]. Thylakoids are the membrane-bound compartments inside chloroplasts that harbors the efficient light for light-dependent photosynthesis reactions by PS I and PS II $[65,66]$. Light energy at the over-saturation point is responsible for photoinhibition by reducing the light-induced photochemical activity in PS II. These negative changes in the photosynthetic electron transport system are mainly responsible for the generation of $\operatorname{ROS}[12,13,67]$. In these connections during overexcitation of chlorophyll, ${ }^{1} \mathrm{O}_{2}$ and $\mathrm{O}_{2}{ }^{-\bullet}$ produce from $\mathrm{O}_{2}$ in PS II (during electron transfer to $\mathrm{O}_{2}$ through $\mathrm{Q}_{\mathrm{A}}$ and $\mathrm{Q}_{\mathrm{B}}$ ) and PS I (Mehler reaction), respectively [68-70]. Peroxisomes can generate $\mathrm{H}_{2} \mathrm{O}_{2}$ by the activities of flavin oxidase, while $\mathrm{O}_{2}{ }^{-\bullet}$ and $\mathrm{H}_{2} \mathrm{O}_{2}$ may be generated in mitochondria of the cell by reducing $\mathrm{O}_{2}$ near the electric transport chain [71-73]. In the present experiment, under the light treatments, L5, L6, L7, and L9 accumulated higher $\mathrm{H}_{2} \mathrm{O}_{2}$ with a lower photosynthetic rate indicating an active production of ROS resulting in photoinhibition and/or overexcitation of chlorophyll. To scavenge the excess ROS produced in the electron transport system plant uses various antioxidative defense mechanisms, including enzymatic and non-enzymatic scavenging procedures, which work synergistically and interactively with each other $[74,75]$.

Lipids and proteins are the primary victims of oxidative damage by ROS accumulated in plant cells [76]. Lipid peroxidation, considered as an indicator of determining the lipid damage extent, occurs in every organism by the oxidative decomposition of polyunsaturated lipids in the plasma membrane under severe conditions [77-79]. However, constant 
stress for plant generates redundant ROS that cannot be entirely homeostated by the scavenging system of the cell and exert some physiological actions like lipid peroxidation, nucleic acid oxidation, protein denaturation, enzyme activity inhibition and finally lead to programmed cell death $[69,76,80]$. In the present study, under the light treatments, L1, L5, L6, and L8 produced higher MDA along with lower photosynthetic rate and water use efficiency, indicating severe lipid damage in the plasma membrane of the plant cell.

\subsection{Effect of LED Spectra on Antioxidant Enzymes Activities}

From our study, the highest and lowest SOD activity was recorded in L7 and L5 treatments, respectively (Figure 4). However, a higher increment was observed from L7 (9.1\%), followed by L11 (6.76\%), L6 (6.58\%), L3 (5.94\%), and L9 (5.89\%), respectively compared to natural light. Higher CAT was recorded in L11 followed by L5, L10, L3, L6, and L7 with $62.88 \%, 45.49 \%, 42.66 \%, 39.11 \%, 38.49 \%$ and $34.9 \%$ increment (compared to natural light), respectively. Higher APX was recorded in L6, followed by L9, L5, L3, and L11, with $81.12 \%, 30.77 \%, 27.97 \%, 12.59 \%$, and $5.59 \%$ increment, respectively, with comparison to natural light. On the other hand, a higher reduction of APX activity was also observed in L4 $(26.57 \%)$ and L8 $(25.17 \%)$. However, higher activity of GPX was observed in L8, L10, L6, L11, L5, and L7 with 92.6\%, 91.6\%, 70.32\%, 44.3\%, 42.8\%, and 39.4\% increment, respectively compared to natural light.

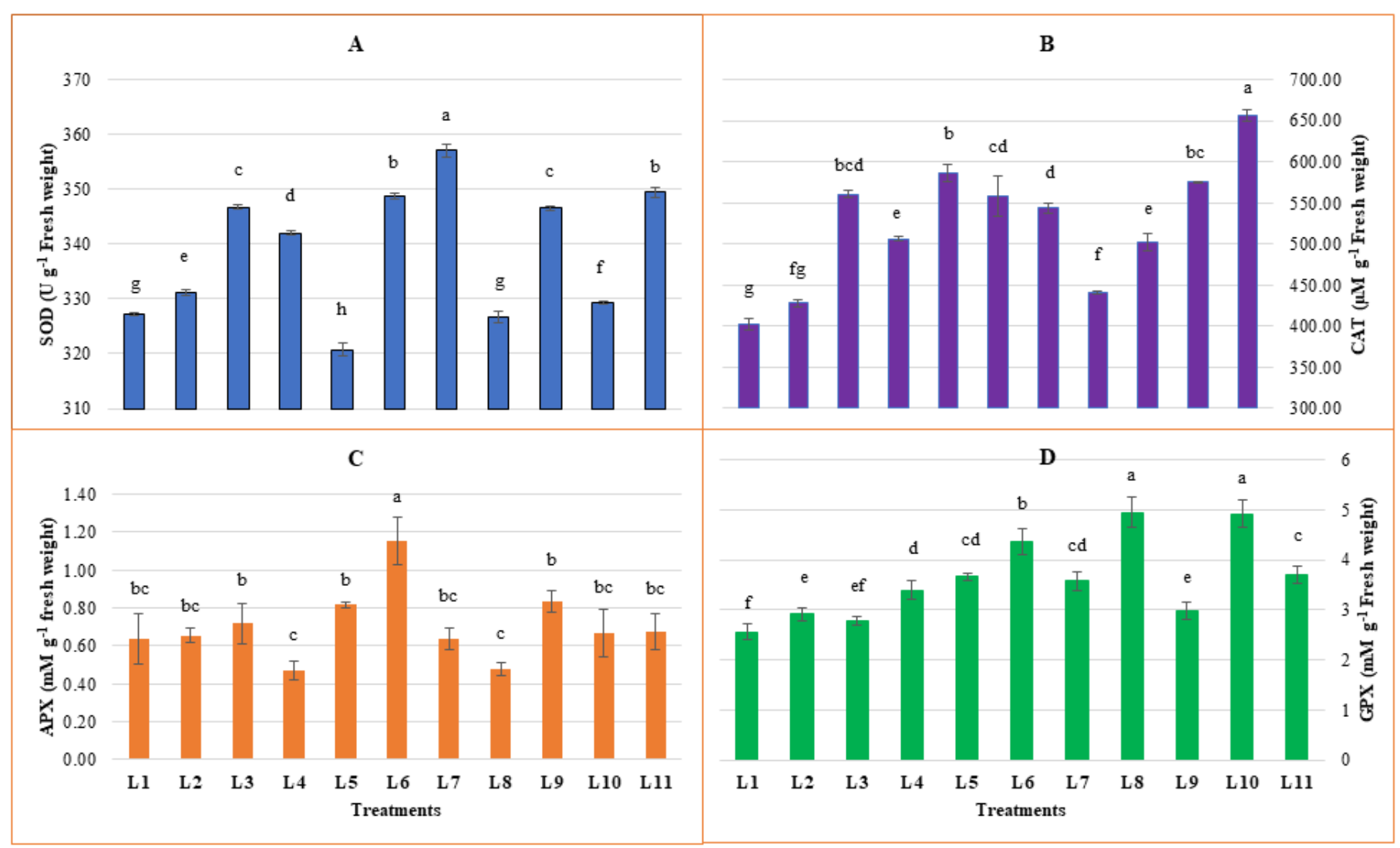

Figure 4. Effect of different LED spectra on Superoxide dismutase (SOD) (A), Catalase (CAT) (B), Ascorbate peroxidase (APX) (C) and Guaiacol peroxidase (GPX) (D) for 20 days on hemp seedlings. Here and subsequent figures: L1, Natural light; L2, White; L3, R8: $\mathrm{B}_{2} ; \mathrm{L} 4, \mathrm{R}_{7}: \mathrm{B}_{2}: \mathrm{G}_{1} ; \mathrm{L} 5, \mathrm{R}_{7}: \mathrm{B}_{2}: \mathrm{FR}_{1} ; \mathrm{L} 6, \mathrm{R}_{6}: \mathrm{B}_{2}: \mathrm{G}_{1}: \mathrm{FR}_{1} ; \mathrm{L7}, \mathrm{R}_{5}: \mathrm{B}_{2}: \mathrm{W}_{2}: \mathrm{FR}_{1} ; \mathrm{L}_{2}, \mathrm{R}_{5}: \mathrm{B}_{2}: \mathrm{G}_{1}: \mathrm{FR}_{1}: \mathrm{UV}_{1} ; \mathrm{L}_{\text {, }}$ $\mathrm{R}_{6}: \mathrm{B}_{2}: \mathrm{FR}_{1}: \mathrm{UV}_{1} ; \mathrm{L} 10, \mathrm{R}_{4}: \mathrm{B}_{2}: \mathrm{W}_{2}: \mathrm{FR}_{1}: \mathrm{UV}_{1} ; \mathrm{L} 11, \mathrm{R}_{2}: \mathrm{B}_{2}: \mathrm{G}_{2}: \mathrm{W}_{2}: \mathrm{FR}_{1}: \mathrm{UV}_{1}$. All treatments used a photosynthetic photon flux density of $300 \mu \mathrm{mol} \mathrm{m} \mathrm{m}^{-2} \mathrm{~s}^{-1}$. Vertical bars indicate mean $\pm \mathrm{SE}$ of four replicates. Different letters indicate significant differences at $p<0.05$. 
ROS accumulated under stress conditions can act as signaling molecules and trigger a signal transduction pathway. It is also crucial that despite causing programmed cell death, ROS is inevitable to confer the resistance to stress. Notably, the activated response created by ROS should be rapid and decay as long as the stress disappeared [75]. The main antioxidant enzymes that play a vital role in detoxifying ROS are SOD, CAT, and APX. SOD converts $\mathrm{O}_{2}{ }^{-}$to $\mathrm{O}_{2}$ and $\mathrm{H}_{2} \mathrm{O}_{2}$, while CAT, APX, and other peroxidase convert $\mathrm{H}_{2} \mathrm{O}_{2}$ to $\mathrm{H}_{2} \mathrm{O}$ and $\mathrm{O}_{2}[19,81]$. In the present experiment in L6 and L7 light treatment, both $\mathrm{H}_{2} \mathrm{O}_{2}$ accumulation and SOD activity was higher, indicating an active mode of stress and plant response to mitigate the ROS compound. Under the light treatment, L1, L5, L6, L8, L10, and L11 plant accumulated higher MDA indicated a secondary damage occurrence is running by lipid peroxidation in the plant cell. At the same time, higher activity of CAT in L3, L5, L6, L10, and L11, higher APX activity from L3, L5, L6 and L9, higher GPX activity from L5, L6, L8 and L10 light spectra were recorded. On the other hand, activity of SOD was found lower in L1, L5, L8 and L10 treatments. Earlier, a decreased SOD and increased APX activity with the increasing MDA accumulation under drought stress were reported [82]. These results indicate that lipid peroxidation may be activated with the lower activity of SOD and higher activity of peroxidases. Generally, elevated oxidative stress stimulates the production of $\mathrm{H}_{2} \mathrm{O}_{2}$ and provokes the increase of antioxidant enzyme activities, which help minimize the negative effect of abiotic stress [83]. A previous study found that a higher irradiance of far-red and red light treatment plants produces higher MDA than lower irradiance [20]. Higher MDA from L5, L6, L8, L10, and L11 compared to other LED spectra in the present study may be due to the presence of far-red light in those spectra.

\subsection{Effect of LED Spectra on Antioxidant Activities}

Total polyphenol (TPC) and total flavonoid (TFC) varied with the spectral variation (Figure 5). Higher TPC was recorded in L6, while both TFC and DPPH free radical scavenging activity (\%) was recorded higher in L7 treatment. Results also showed that both TPC and TFC increased under L2, L6, L7, L8, L9, and L10 treatments compare to natural light, while DPPH free radical scavenging activity (\%) increased under L2, L6, L7, L8, and L9 treatments.

Generally, the cytokinin level increased by a red light that can stimulate the synthesis of phenolics compound, where far-red helps increase the plants' antioxidant capacity [84,85]. A previous study of both phenolic compound and antioxidant capacity decreased under a combination of red and blue compared to monochromatic red, blue, and natural light [18]. Therefore, the intensity of red light and its ratio with other light sources may contribute to secondary metabolites production. Further, secondary metabolites and antioxidant capacities can vary with the light intensities and ratio of monochromatic light sources [86-88]. In our study, both TPC and TFC decreased at $\geq 70 \%$ and increased at $50-60 \%$, while it turned to dropped at $<40 \%$ red light sources compare to natural light. Supplementary UV radiation can increase flavanols and other secondary metabolites that act as a stress response to protect plants from radiation $[17,89]$. In our study, UV A radiation was observed prominent with a $60 \%$ red light source. Artificial blue LED and far-red light enhance secondary metabolites, and the nutritional quality of crops, including ascorbate, total phenolic compounds, total flavonoid contents, and antioxidant activity, have been reported $[88,90]$. We also found an increment of secondary metabolites with the addition of FR light, but the effect of FR light was found prominent with 50-60\% red light sources. A previous study stated that increasing intensity of red to blue increased plant flavonoid, which was found best at 7:3 ratio [87]. Our research also produces higher flavonoids at L6, L7, L8, and L9 treatments with similar red and blue ratios. 


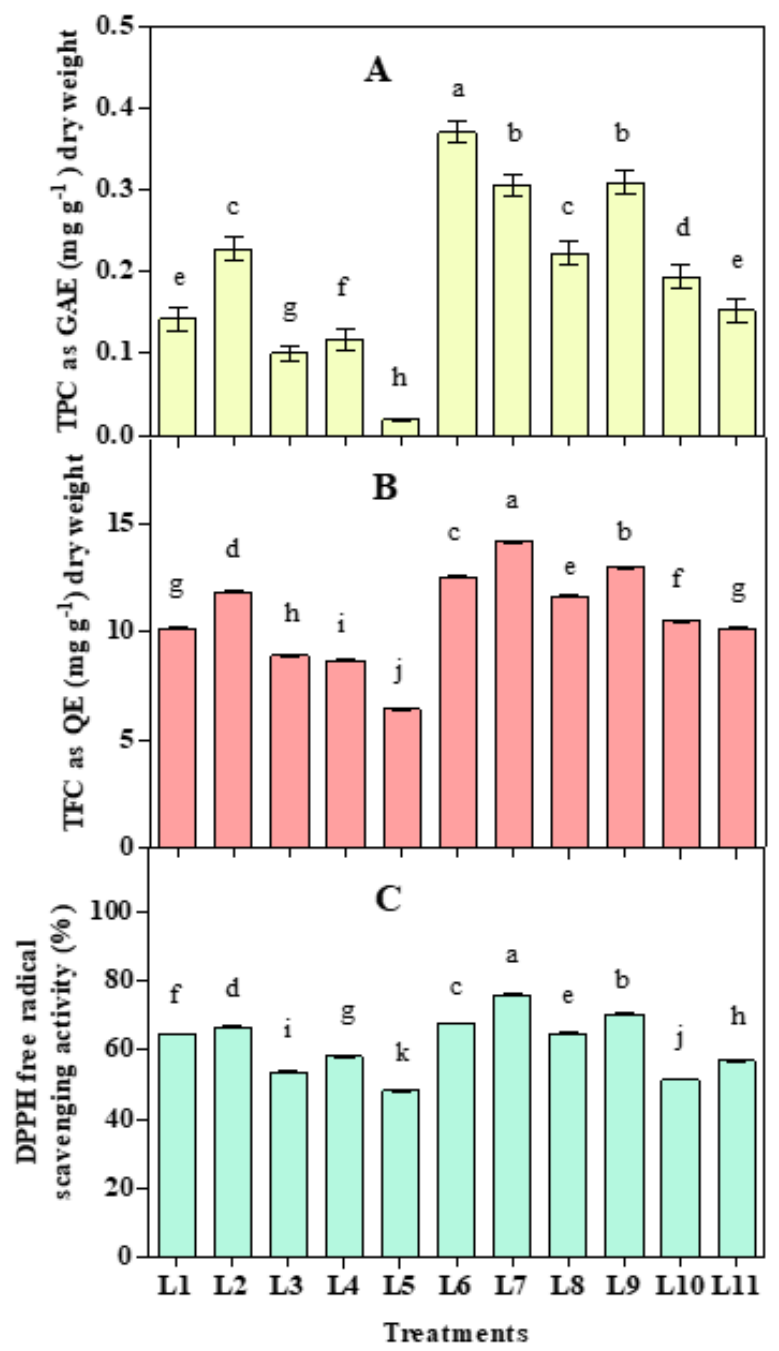

Figure 5. Effect of 20 days exposure to different LED spectra on Total polyphenol (TPC) (A), Total flavonoid (TFC) (B), and DPPH radical scavenging activity (C) of hemp seedlings. Here and subsequent figures: L1, Natural light; L2, White; $L 3, \mathrm{R}_{8}: \mathrm{B}_{2} ; \mathrm{L} 4, \mathrm{R}_{7}: \mathrm{B}_{2}: \mathrm{G}_{1} ; \mathrm{L} 5, \mathrm{R}_{7}: \mathrm{B}_{2}: \mathrm{FR}_{1} ; \mathrm{L} 6$, $\mathrm{R}_{6}: \mathrm{B}_{2}: \mathrm{G}_{1}: \mathrm{FR}_{1} ; \mathrm{L7}, \mathrm{R}_{5}: \mathrm{B}_{2}: \mathrm{W}_{2}: \mathrm{FR}_{1} ; \mathrm{L} 8, \mathrm{R}_{5}: \mathrm{B}_{2}: \mathrm{G}_{1}: \mathrm{FR}_{1}: \mathrm{UV}_{1} ; \mathrm{L}, \mathrm{R}_{6}: \mathrm{B}_{2}: \mathrm{FR}_{1}: \mathrm{UV}_{1} ; \mathrm{L} 10, \mathrm{R}_{4}: \mathrm{B}_{2}: \mathrm{W}_{2}: \mathrm{FR}_{1}: \mathrm{UV}_{1}$; L11, $R_{2}: B_{2}: G_{2}: W_{2}: F_{1}: U_{1}$. All treatments used a photosynthetic photon flux density of $300 \mu \mathrm{mol} \mathrm{m} \mathrm{m}^{-2} \mathrm{~s}^{-1}$. Vertical bars indicate mean \pm SE of four replicates. Different letters indicate significant differences at $p<0.05$.

\subsection{Effect of LED Spectra on THC, THCA, CBD, and CBDA}

Significant $(p<0.05)$ variations in the Tetrahydrocannabinol (THC), Tetrahydrocannabinolic acid (THCA), Cannabidiol (CBD), and Cannabidiolic acid (CBDA) were observed under different LED spectra (Figure 6). Plant accumulated higher CBD in L4 (48.01 $\left.\mu \mathrm{g} \mathrm{g}^{-1} \mathrm{DW}\right), \mathrm{L} 5\left(10.44 \mu \mathrm{g} \mathrm{g}^{-1} \mathrm{DW}\right)$, and L8 (12.90 $\left.\mu \mathrm{g} \mathrm{g}^{-1} \mathrm{DW}\right)$ while higher THC in all light spectra compare to natural light. Notably, CBD and THC showing a positive relationship in L4, L5, and L8 spectra, where both CBD and THC increased significantly. On the other hand, an opposite relationship was observed in L2, L3, L7, L9, L10, and L11 spectra, where THC and CBD showed an increasing and decreasing trend, respectively. Higher CBDA was accumulated under all spectra except L7, and higher THCA was accumulated under all spectra except L10 compared to natural light. Interestingly, L7 produced an antagonistic relationship, while others produced an almost positive relationship between THCA and CBDA accumulation. 


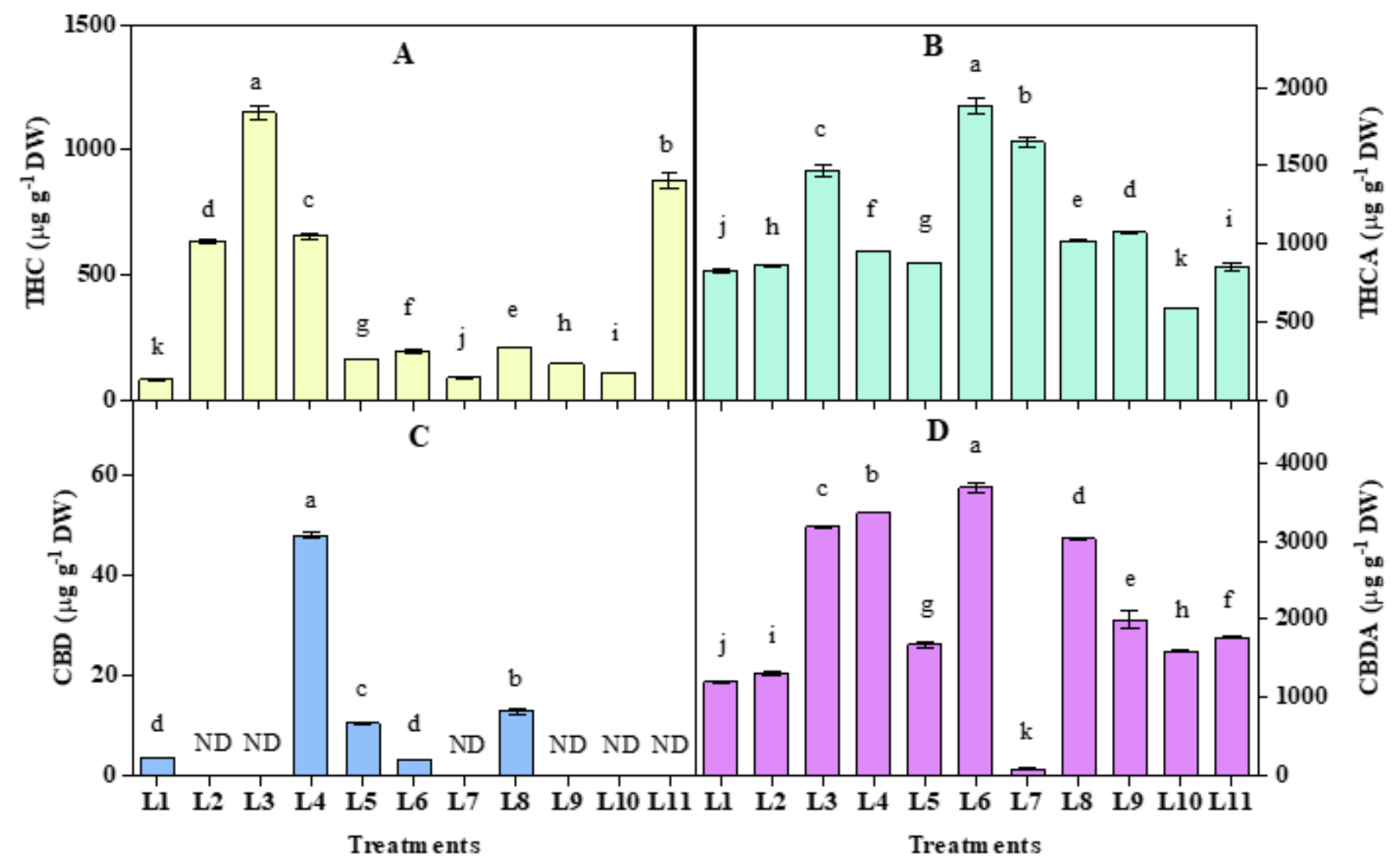

Figure 6. Effect of 20 days exposure to different LED spectra on Tetrahydrocannabinol (THC) (A), Tetrahydrocannabinolic acid (THCA) (B) Cannabidiol (CBD) (C), and Cannabidiolic acid (CBDA) (D) of hemp seedlings. Here and subsequent figures: L1, Natural light; L2, White; L3, $\mathrm{R}_{8}: \mathrm{B}_{2} ; \mathrm{L} 4, \mathrm{R}_{7}: \mathrm{B}_{2}: \mathrm{G}_{1} ; \mathrm{L} 5, \mathrm{R}_{7}: \mathrm{B}_{2}: \mathrm{FR}_{1} ; \mathrm{L6}, \mathrm{R}_{6}: \mathrm{B}_{2}: \mathrm{G}_{1}: \mathrm{FR}_{1} ; \mathrm{L}, \mathrm{R}_{5}: \mathrm{B}_{2}: \mathrm{W}_{2}: \mathrm{FR}_{1} ; \mathrm{L}_{\text {, }}$ $\mathrm{R}_{5}: \mathrm{B}_{2}: \mathrm{G}_{1}: \mathrm{FR}_{1}: \mathrm{UV}_{1} ; \mathrm{L} 9, \mathrm{R}_{6}: \mathrm{B}_{2}: \mathrm{FR}_{1}: \mathrm{UV}_{1} ; \mathrm{L} 10, \mathrm{R}_{4}: \mathrm{B}_{2}: \mathrm{W}_{2}: \mathrm{FR}_{1}: \mathrm{UV}_{1} ; \mathrm{L} 11, \mathrm{R}_{2}: \mathrm{B}_{2}: \mathrm{G}_{2}: \mathrm{W}_{2}: \mathrm{FR}_{1}: \mathrm{UV}_{1}$. All treatments used a photosynthetic photon flux density of $300 \mu \mathrm{mol} \mathrm{m} \mathrm{m}^{-2} \mathrm{~s}^{-1}$. Vertical bars indicate mean $\pm \mathrm{SE}$ of four replicates. Different letters indicate significant differences at $p<0.05$.

In general, CBGA produces by alkylation of two precursors olivetolic acid and geranyl pyrophosphate, with the help of geranyl pyrophosphate:olivatolate geranyl transferase [91,92], which further can convert to THCA by THCA synthase [93,94] and CBDA by CBDA synthase [95] in the oxidation process (Figure 7). In this connection, during oxidation of CBGA, it produces hydrogen peroxide and THCA in THCA synthase reaction [96], which may play a role in the self-defense of cannabis plants [94]. Furthermore, light quality may play an essential role in cannabinoid synthesis as light intensity influences cannabis yields strongly $[41,97]$. We observed both higher THCA and $\mathrm{H}_{2} \mathrm{O}_{2}$ accumulation in L6 and L7 spectra in the present study, but we did not find any clear relation between THC and $\mathrm{H}_{2} \mathrm{O}_{2}$ from this observation. THCA also showed a positive relationship with antioxidant activities and antioxidant enzymes in L6, L7, L8, and L9 treatments.

On the other hand, it showed a negative relationship with the photosynthetic rate in the above four treatments. In the present study, except L11, THC accumulation was most prominent in $\mathrm{L} 2$ (white), L3 $\left(\mathrm{R}_{8} \mathrm{~B}_{2}\right)$, and $\mathrm{L} 4\left(\mathrm{R}_{7} \mathrm{~B}_{2} \mathrm{G}_{1}\right)$ spectra, where we can assume very little influence of FR and UV A light on THC accumulation in cannabis plants. It was also reported that Cannabis plants were grown under blue, and synergy between UV-A and blue light improved cannabinoid and cannabigerol accumulation, respectively [98]. We also found higher THCA, CBDA, and THC concentrations under UV-A mediated spectral combinations. 


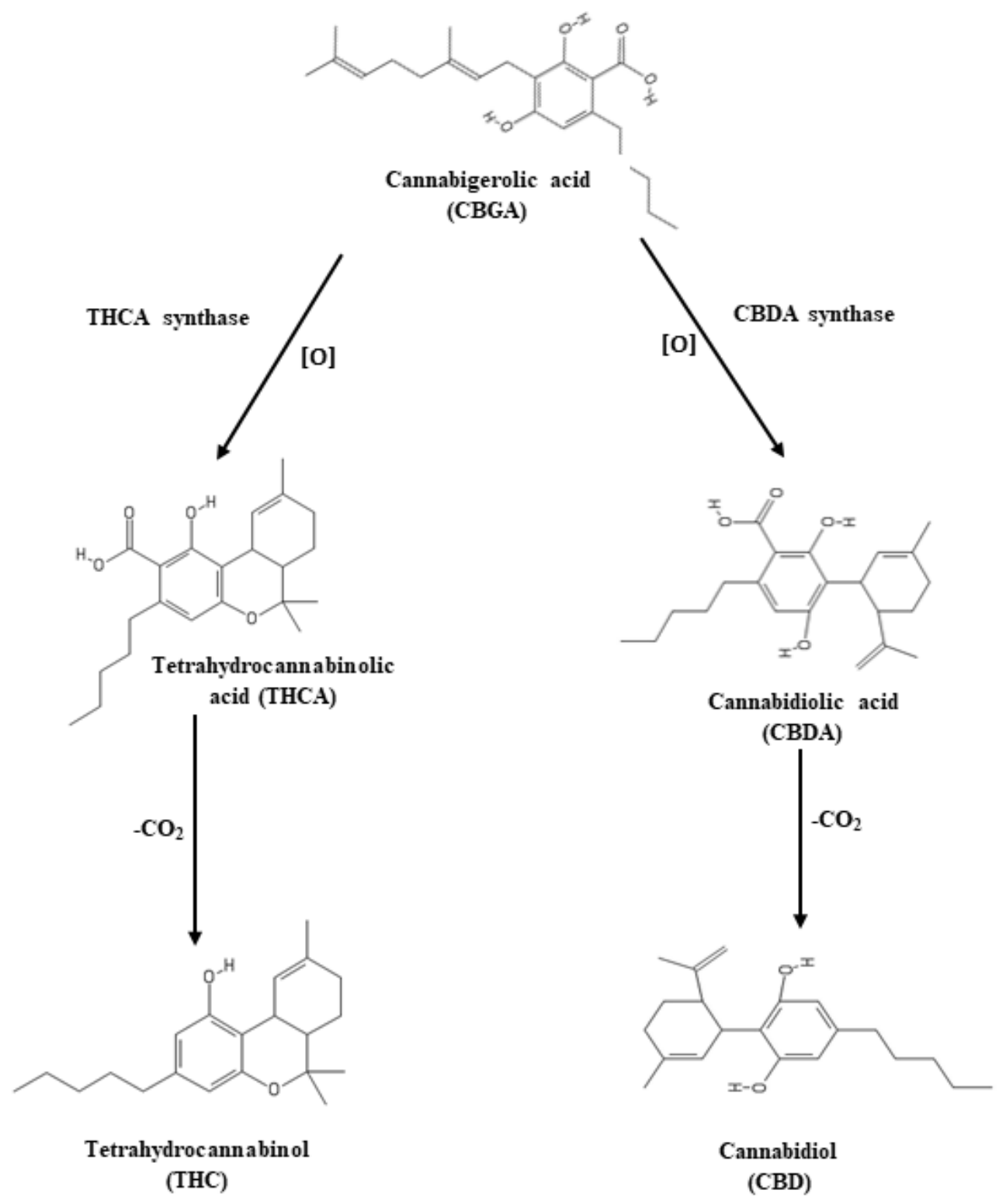

Figure 7. Biosynthetic pathway of THC and CBD formation. THCA synthase and CBDA synthase catalyze oxidative cyclization of the monoterpene moiety of CBGA to form THCA and CBDA. THC and CBD are derived by non-enzymatic decarboxylation of THCA and CBDA.

On the other hand, CBD and CBDA accumulated higher in L4, L5, L6, and L8. From these results, we can see that green light has a significant role in CBDA synthesis and its conversion to CBD. Notably, FR light also influences CBDA and CBD accumulation along with green light, where white and UV-A play a negative role in this process. In some previous studies, the role of green light was shown negative for THC accumulation [7,99], but its role in $\mathrm{CBD}$ and $\mathrm{CBDA}$ synthesis was not clear. Results also depicted that the total THC (THC + THCA) was accumulated higher in L3, L6, L7, and L11, while total $\mathrm{CBD}(\mathrm{CBD}+\mathrm{CBDA})$ was recorded higher in L3, L4, L6, and L8 treatments (Supplementary Figure S2). However, due to their importance, higher THC accumulation in L2, L3, L4, and L11 and higher CBD in L4 and L8 treatments got more attention in this study. Despite having some shreds of evidence in the previous studies $[46,100,101]$, the complex functions of cannabinoids relate to the defensive role toward biotic and abiotic stresses are not clear. Among the cannabinoids, THC and CBD were most discussed for having their antioxidant properties [102]. Earlier, THC, THCA, CBD, and CBDA were predicted as stress indicators 
along with some other secondary metabolites in the hemp plant under controlled drought stress [100]. It was also reported that THCA induces necrotic cell death in Cannabis cells and leaves [103]. The increasing cannabinoids in the present study also indicated a stress response of the cannabis plant under some controlled LED light spectral treatments.

\subsection{Hierarchical Clustering and Heatmap Unveiled the Connections between Variables and Treatments}

The values of all physiological and biochemical parameters of different light treatments were employed to construct the hierarchical clustering and a heatmap (Figure 8a). Hierarchical clustering grouped all the variables into two major clusters (cluster-A and cluster-B). Hierarchical clustering and heatmap revealed that all the parameters characterized cluster-A relate to abiotic stress, such as MDA, $\mathrm{H}_{2} \mathrm{O}_{2}$, SOD, CAT, APX, GPX, TPC, TFC, DPPH, and THCA. All the cluster-A variables showed minimal values at L1, L2, L3, and L4, which indicated low comparative stress for hemp, whereas L6 and L7 treatments increased this trend. On the other hand, cluster-B represents all photosynthetic attributes $\left(\mathrm{P}_{\mathrm{n}}, \mathrm{E}, \mathrm{g}_{\mathrm{s}}\right.$, and WUE) and cannabinoids like CBD, CBDA, and THC. All cluster-B variables showed maximum values at $\mathrm{L} 4$ followed by $\mathrm{L} 8, \mathrm{~L} 2$, and $\mathrm{L} 3$. This result is indicating that $\mathrm{CBD}$ and THC have a negligible relationship with stress-producing compounds. On the other hand, CBDA has a small extent of the relationship with stress compounds as it increased a little at stress-producing light like L6. Interestingly, the treatment L4 exhibited minimum and maximum values of almost all cluster-A and cluster-B parameters, respectively.

PCA analysis was carried out to uncover the connection of the different parameters with different treatment groups (Figure 8b). The two elements of PCA (PC1 and PC2) together described $46.59 \%$ of data variability. The results demonstrated an intimate association of cluster A variables with mainly L6 and L7 treatments. Results also displayed that some variables related to stress responses $\left(\mathrm{H}_{2} \mathrm{O}_{2}, \mathrm{MDA}, \mathrm{TPC}, \mathrm{TFC}, \mathrm{DPPH}, \mathrm{SOD}\right.$, and APX) were negatively correlated to $\mathrm{CBD}$, and $\mathrm{CBDA}$ while THC maintained a positive correlation in most cases, which is also confirmed by bivariate correlation (Supplementary Table S1). Besides, treatment L4 showed an intimate relationship with THC, CBD, and CBDA. 

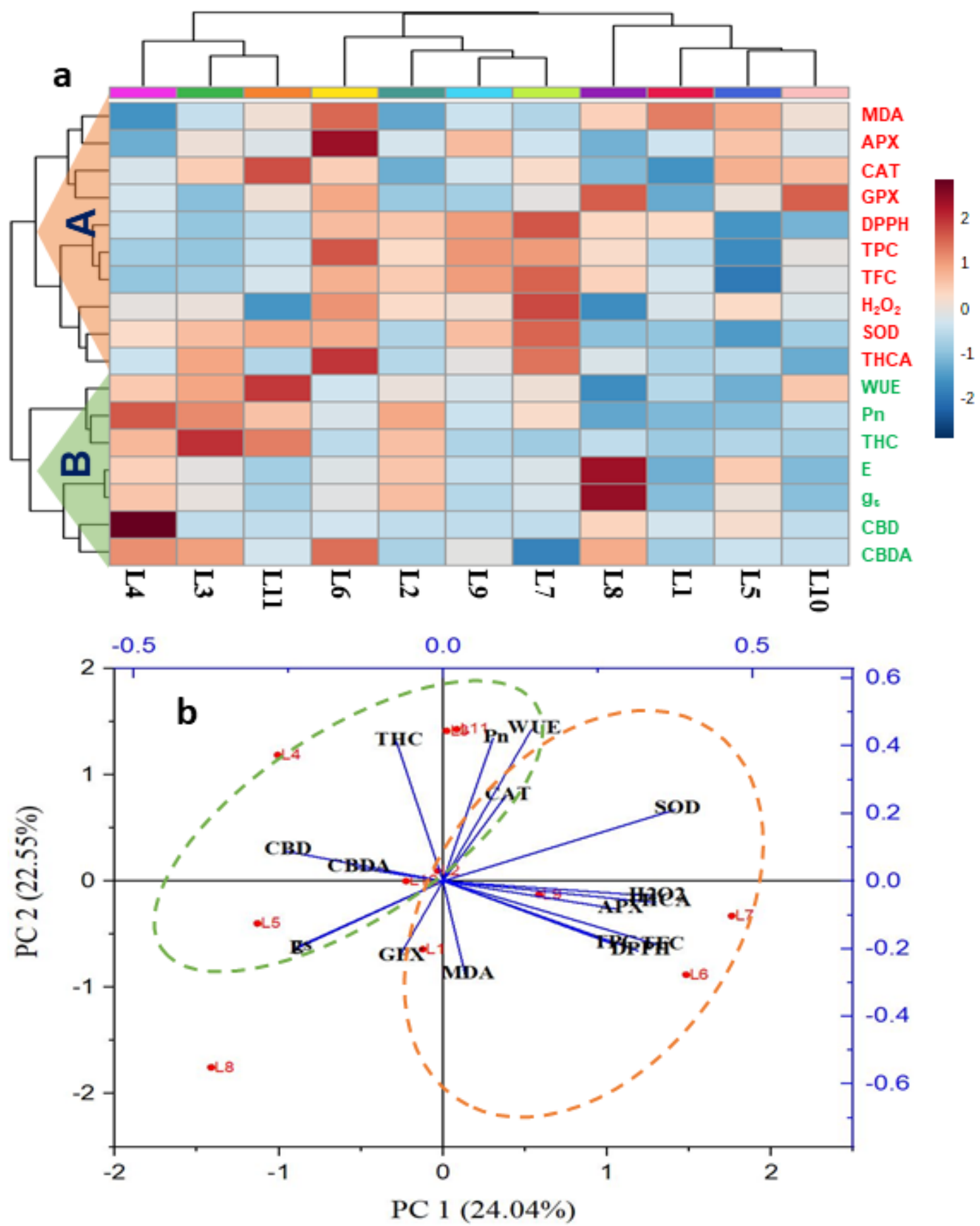

Figure 8. Hierarchical clustering and heatmap analysis (a) and principal component analysis (PCA) (b) to elucidate the variable treatment relationships under eleven treatments for 20 days. In the heatmap, the mean values of the various parameters obtained in this study were normalized and clustered. At the variable level, two major clusters were recognized for each treatment. The color scale displays the intensity of normalized mean values of different parameters. In PCA, the lines starting from the central point of the biplots display negative or positive associations of different variables, and their proximity specifies the degree of correlation with specific treatment. L1, Natural light; $L 2$, White; $L 3, R_{8}: B_{2} ; L 4, R_{7}: B_{2}: G_{1}$; L5, $\mathrm{R}_{7}: \mathrm{B}_{2}: \mathrm{FR}_{1} ; \mathrm{L6}, \mathrm{R}_{6}: \mathrm{B}_{2}: \mathrm{G}_{1}: \mathrm{FR}_{1} ; \mathrm{L7}, \mathrm{R}_{5}: \mathrm{B}_{2}: \mathrm{W}_{2}: \mathrm{FR}_{1} ; \mathrm{L} 8, \mathrm{R}_{5}: \mathrm{B}_{2}: \mathrm{G}_{1}: \mathrm{FR}_{1}: \mathrm{UV}_{1} ; \mathrm{L}_{1}, \mathrm{R}_{6}: \mathrm{B}_{2}: \mathrm{FR}_{1}: \mathrm{UV}_{1} ; \mathrm{L}_{10}, \mathrm{R}_{4}: \mathrm{B}_{2}: \mathrm{W}_{2}: \mathrm{FR}_{1}: \mathrm{UV}_{1} ; \mathrm{L}_{11}$, $\mathrm{R}_{2}: \mathrm{B}_{2}: \mathrm{G}_{2}: \mathrm{W}_{2}: \mathrm{FR}_{1}: \mathrm{UV}_{1}$. Pn, photosynthetic rate; E, transpiration rate; gs, stomatal conductivity; WUE, water use efficiency; MDA, malondialdehyde; $\mathrm{H}_{2} \mathrm{O}_{2}$, hydrogen peroxide; $\mathrm{SOD}$, superoxide dismutase; $\mathrm{CAT}$, catalase; APX, ascorbate peroxidase; GPX, guaiacol peroxidase; TPC, total polyphenol; TFC, total flavonoid; DPPH, DPPH radical scavenging activity; CBD, cannabidiol; CBDA, cannabidiolic acid; THC, Tetrahydrocannabinol; THCA, Tetrahydrocannabinolic acid. 


\section{Conclusions}

Higher CBD was accumulated in $\mathrm{L} 4\left(\mathrm{R}_{7}: \mathrm{B}_{2}: \mathrm{G}_{1}\right)$, L5 $\left(\mathrm{R}_{7}: \mathrm{B}_{2}: \mathrm{FR}_{1}\right)$, and $\mathrm{L} 8\left(\mathrm{R}_{5}: \mathrm{B}_{2}: \mathrm{G}_{1}\right.$ : $\mathrm{FR}_{1}: \mathrm{UV}_{1}$ ), while higher THC in all light spectra compare to natural light. On the other hand, higher CBDA synthesis was recorded in $\mathrm{L} 3\left(\mathrm{R}_{8}: \mathrm{B}_{2}\right), \mathrm{L} 4\left(\mathrm{R}_{7}: \mathrm{B}_{2}: \mathrm{G}_{1}\right), \mathrm{L} 6\left(\mathrm{R}_{6}: \mathrm{B}_{2}: \mathrm{G}_{1}: \mathrm{FR}_{1}\right)$, and $\mathrm{L} 8\left(\mathrm{R}_{5}: \mathrm{B}_{2}: \mathrm{G}_{1}: \mathrm{FR}_{1}: \mathrm{UV}_{1}\right)$ treatments. The treatment $\mathrm{L} 4\left(\mathrm{R}_{7}: \mathrm{B}_{2}: \mathrm{G}_{1}\right)$ produced all cannabinoids (CBD, CBDA, THC, and THCA) in higher concentration with lower stress response compounds like reactive oxygen species, antioxidants, THCA, and enzymatic activities. Besides this, the treatments L6 $\left(\mathrm{R}_{6}: \mathrm{B}_{2}: \mathrm{G}_{1}: \mathrm{FR}_{1}\right)$ showed a lower CBD and THC and higher THCA and CBDA accumulation with higher activities of all other stress response compounds. On the other hand, $\mathrm{L} 7\left(\mathrm{R}_{5}: \mathrm{B}_{2}: \mathrm{W}_{2}: \mathrm{FR}_{1}\right)$ produced lower $\mathrm{CBD}, \mathrm{THC}$, and CBDA with a higher accumulation of all other stress-responsive compounds, including THCA. Besides, Greenlight has a significant role in CBD and CBDA synthesis where FR and UV-A (along with green) play a positive and negative role in this process, respectively. From our result, THCA showed a significant role as a stress marker followed by CBDA. On the other hand, THC and CBD showed a negligible response as stress response compounds to such conditions.

Supplementary Materials: The following are available online at https:/ / www.mdpi.com/article/10 $.3390 /$ biology10080710/s1, Figure S1: The retention time of CBD (4.34 min), CBDA (3.60 min), THC (9.60 $\mathrm{min})$, and THCA (13.00 $\mathrm{min})$, Figure S2: Effect of 20 days exposure to different LED spectra on total THC (THC + THCA; A), and total CBD (CBD + CBDA; B) of hemp seedlings, Table S1: The bivariate correlations among the parameters under 11 treatments.

Author Contributions: M.J.I. conceived and designed the experiments, carried out all the experimental works, collected, analyzed the data, and drafted the final manuscript. B.R.R. and M.H.R. contributed to collecting data and preparing experimental works. M.O.K.A. and E.J.C. improved the manuscript. J.-D.L. and Y.-S.L. validated all the protocols and supervised the study. All authors read and approved the final manuscript.

Funding: This research did not receive any specific grant.

Institutional Review Board Statement: Not applicable.

Informed Consent Statement: The study followed the relevant institutional and national guidelines and legislation, with research permission (license number 1770) from the Ministry of Food and Drug Safety (MFDS), Korea.

Data Availability Statement: Not applicable.

Acknowledgments: This research was supported by the Ministry of Science and ICT (MSIT, Korea, (support program: 2021-DD-UP-0379) and the BK21 FOUR program of the National Research Foundation (NRF, Korea). The authors also express their gratitude and profound appreciation to the CBF (Chuncheon Bioindustry Foundation, Korea) and Chuncheon City for their support in hemp variety breeding project.

Conflicts of Interest: The authors declare no competing interest.

\section{References}

1. Bayat, L.; Arab, M.; Aliniaeifard, S.; Seif, M.; Lastochkina, O.; Li, T. Effects of growth under different light spectra on the subsequent high light tolerance in rose plants. AoB Plants 2018, 10, ply052. [CrossRef]

2. Islam, M.J.; Hassan, M.K.; Sarker, S.R.; Rahman, A.B.; Fakir, M.S.A. Light and temperature effects on sprout yield and its proximate composition and vitamin C content in lignosus and mung beans. J. Bangladesh Agric. Univ. 2017, 15, 248-254. [CrossRef]

3. Ouzounis, T.; Rosenqvist, E.; Ottosen, C.-O. Spectral effects of artificial light on plant physiology and secondary metabolism: A review. HortScience 2015, 50, 1128-1135. [CrossRef]

4. Kozai, T. Why LED lighting for urban agriculture? In LED Lighting for Urban Agriculture; Springer: Berlin/Heidelberg, Germany, 2016; pp. 3-18.

5. Li, P.; Ma, F. Different effects of light irradiation on the photosynthetic electron transport chain during apple tree leaf dehydration. Plant Physiol. Biochem. 2012, 55, 16-22. [CrossRef]

6. Sæbø, A.; Krekling, T.; Appelgren, M. Light quality affects photosynthesis and leaf anatomy of birch plantlets in vitro. Plant Cell. Tissue Organ Cult. 1995, 41, 177-185. [CrossRef] 
7. Eichhorn Bilodeau, S.; Wu, B.-S.; Rufyikiri, A.-S.; MacPherson, S.; Lefsrud, M. An update on plant photobiology and implications for cannabis production. Front. Plant Sci. 2019, 10, 296. [CrossRef] [PubMed]

8. Lazar, T. Plant Physiology, 3rd ed.; Elsevier: Amsterdam, The Netherlands, 2003.

9. Li, Q.; Kubota, C. Effects of supplemental light quality on growth and phytochemicals of baby leaf lettuce. Environ. Exp. Bot. 2009, 67, 59-64. [CrossRef]

10. Carvalho, S.D.; Schwieterman, M.L.; Abrahan, C.E.; Colquhoun, T.A.; Folta, K.M. Light quality dependent changes in morphology, antioxidant capacity, and volatile production in sweet basil (Ocimum basilicum). Front. Plant Sci. 2016, 7, 1328. [CrossRef]

11. Hideg, É.; Jansen, M.A.K.; Strid, Å. UV-B exposure, ROS, and stress: Inseparable companions or loosely linked associates? Trends Plant Sci. 2013, 18, 107-115. [CrossRef]

12. Gu, J.; Zhou, Z.; Li, Z.; Chen, Y.; Wang, Z.; Zhang, H.; Yang, J. Photosynthetic properties and potentials for improvement of photosynthesis in pale green leaf rice under high light conditions. Front. Plant Sci. 2017, 8, 1082. [CrossRef]

13. Miyake, C.; Amako, K.; Shiraishi, N.; Sugimoto, T. Acclimation of tobacco leaves to high light intensity drives the plastoquinone oxidation system - relationship among the fraction of open PSII centers, non-photochemical quenching of Chl fluorescence and the maximum quantum yield of PSII in the dark. Plant Cell Physiol. 2009, 50, 730-743. [CrossRef] [PubMed]

14. Vranová, E.; Inzé, D.; Van Breusegem, F. Signal transduction during oxidative stress. J. Exp. Bot. 2002, 53, 1227-1236. [CrossRef]

15. Noodén, L.D.; Schneider, M.J. Light control of senescence. In Plant Cell Death Processes; Elsevier: Amsterdam, The Netherlands, 2004; pp. 375-383.

16. Hopkins, W.G.; Hüner, N.P.A. Secondary metabolites. In Introduction to Plant Physiology, 4th ed.; John Wiley Sons, Inc.: Hoboken, NJ, USA, 2008.

17. Thoma, F.; Somborn-Schulz, A.; Schlehuber, D.; Keuter, V.; Deerberg, G. Effects of Light on Secondary Metabolites in Selected Leafy Greens: A Review. Front. Plant Sci. 2020, 11, 497. [CrossRef]

18. Azad, M.O.K.; Chun, I.J.; Jeong, J.H.; Kwon, S.T.; Hwang, J.M. Response of the growth characteristics and phytochemical contents of pepper (Capsicum annuum L.) seedlings with supplemental LED light in glass house. Prot. Hortic. Plant Fact. 2011, 20, 182-188.

19. Poór, P.; Ördög, A.; Czékus, Z.; Borbély, P.; Takács, Z.; Kovács, J.; Tari, I. Regulation of the key antioxidant enzymes by developmental processes and environmental stresses in the dark. Biol. Plant. 2018, 62, 201-210. [CrossRef]

20. Cao, K.; Yu, J.; Xu, D.; Ai, K.; Bao, E.; Zou, Z. Exposure to lower red to far-red light ratios improve tomato tolerance to salt stress. BMC Plant Biol. 2018, 18, 92. [CrossRef] [PubMed]

21. Hasan, M.; Bae, H. An overview of stress-induced resveratrol synthesis in grapes: Perspectives for resveratrol-enriched grape products. Molecules 2017, 22, 294. [CrossRef] [PubMed]

22. Hasan, M.; Bashir, T.; Ghosh, R.; Lee, S.K.; Bae, H. An overview of LEDs' effects on the production of bioactive compounds and crop quality. Molecules 2017, 22, 1420. [CrossRef]

23. Gundel, P.E.; Pierik, R.; Mommer, L.; Ballaré, C.L. Competing neighbors: Light perception and root function. Oecologia 2014, 176, 1-10. [CrossRef]

24. Blilou, I.; Xu, J.; Wildwater, M.; Willemsen, V.; Paponov, I.; Friml, J.; Heidstra, R.; Aida, M.; Palme, K.; Scheres, B. The PIN auxin efflux facilitator network controls growth and patterning in Arabidopsis roots. Nature 2005, 433, 39-44. [CrossRef] [PubMed]

25. Van Gelderen, K.; Kang, C.; Paalman, R.; Keuskamp, D.; Hayes, S.; Pierik, R. Far-red light detection in the shoot regulates lateral root development through the HY5 transcription factor. Plant Cell 2018, 30, 101-116. [CrossRef] [PubMed]

26. Samuolienè, G.; Viršilè, A.; Miliauskienè, J.; Haimi, P.; Laužikè, K.; Jankauskienè, J.; Novičkovas, A.; Kupčinskienė, A.; Brazaitytè, A. The Photosynthetic Performance of Red Leaf Lettuce under UV-A Irradiation. Agronomy 2020, 10, 761. [CrossRef]

27. Jenkins, G.I. Signal transduction in responses to UV-B radiation. Annu. Rev. Plant Biol. 2009, 60, 407-431. [CrossRef]

28. Robson, T.M.; Klem, K.; Urban, O.; Jansen, M.A.K. Re-interpreting plant morphological responses to UV-B radiation. Plant. Cell Environ. 2015, 38, 856-866. [CrossRef]

29. Escobar-Bravo, R.; Klinkhamer, P.G.L.; Leiss, K.A. Interactive effects of UV-B light with abiotic factors on plant growth and chemistry, and their consequences for defense against arthropod herbivores. Front. Plant Sci. 2017, 8, 278. [CrossRef] [PubMed]

30. Katerova, Z.; Todorova, D.; Tasheva, K.; Sergiev, I. Influence of ultraviolet radiation on plant secondary metabolite production. Genet Plant Physiol 2012, 2, 113-144.

31. Rizzini, L.; Favory, J.-J.; Cloix, C.; Faggionato, D.; O’Hara, A.; Kaiserli, E.; Baumeister, R.; Schäfer, E.; Nagy, F.; Jenkins, G.I. Perception of UV-B by the Arabidopsis UVR8 protein. Science 2011, 332, 103-106. [CrossRef] [PubMed]

32. Kalaitzoglou, P.; Van Ieperen, W.; Harbinson, J.; van der Meer, M.; Martinakos, S.; Weerheim, K.; Nicole, C.; Marcelis, L.F.M. Effects of continuous or end-of-day far-red light on tomato plant growth, morphology, light absorption, and fruit production. Front. Plant Sci. 2019, 10, 322. [CrossRef] [PubMed]

33. Ádám, É.; Hussong, A.; Bindics, J.; Wüst, F.; Viczián, A.; Essing, M.; Medzihradszky, M.; Kircher, S.; Schäfer, E.; Nagy, F. Altered dark-and photoconversion of phytochrome B mediate extreme light sensitivity and loss of photoreversibility of the phyB-401 mutant. PLoS ONE 2011, 6, e27250. [CrossRef]

34. Possart, A.; Xu, T.; Paik, I.; Hanke, S.; Keim, S.; Hermann, H.-M.; Wolf, L.; Hiß, M.; Becker, C.; Huq, E. Characterization of phytochrome interacting factors from the moss Physcomitrella patens illustrates conservation of phytochrome signaling modules in land plants. Plant Cell 2017, 29, 310-330. [CrossRef] 
35. Sheerin, D.J.; Menon, C.; zur Oven-Krockhaus, S.; Enderle, B.; Zhu, L.; Johnen, P.; Schleifenbaum, F.; Stierhof, Y.-D.; Huq, E.; Hiltbrunner, A. Light-activated phytochrome A and B interact with members of the SPA family to promote photomorphogenesis in Arabidopsis by reorganizing the COP1/SPA complex. Plant Cell 2015, 27, 189-201. [CrossRef]

36. Ryu, B.R.; Islam, M.; Azad, M.; Kalam, O.; Go, E.-J.; Rahman, M.; Rana, M.; Lim, Y.-S.; Lim, J.-D. Conversion Characteristics of Some Major Cannabinoids from Hemp (Cannabis sativa L.) Raw Materials by New Rapid Simultaneous Analysis Method. Molecules 2021, 26, 4113. [CrossRef]

37. Muntendam, R.; Happyana, N.; Erkelens, T.; Bruining, F.; Kayser, O. Time dependent metabolomics and transcriptional analysis of cannabinoid biosynthesis in Cannabis sativa var. Bedrobinol and Bediol grown under standardized condition and with genetic homogeneity. Online Int. J. Med. Plant Res 2012, 1, 31-40.

38. Ross, S.A.; ElSohly, M.A. CBN and $\triangle$ 9-THC concentration ratio as an indicator of the age of stored marijuana samples. Bull. Narc. 1997, 49, 139.

39. Taschwer, M.; Schmid, M.G. Determination of the relative percentage distribution of THCA and $\triangle 9$-THC in herbal cannabis seized in Austria-Impact of different storage temperatures on stability. Forensic Sci. Int. 2015, 254, 167-171. [CrossRef] [PubMed]

40. Kimura, M.; Okamoto, K. Distribution of tetrahydrocannabinolic acid in fresh wild Cannabis. Experientia 1970, 26, 819-820. [CrossRef]

41. Lydon, J.; Teramura, A.H.; Coffman, C.B. UV-B radiation effects on photosynthesis, growth and cannabinoid production of two Cannabis sativa chemotypes. Photochem. Photobiol. 1987, 46, 201-206. [CrossRef]

42. Potter, D.J.; Duncombe, P. The Effect of Electrical Lighting Power and Irradiance on Indoor-Grown Cannabis Potency and Yield. J. Forensic Sci. 2012, 57, 618-622. [CrossRef]

43. Potter, D. The Propagation, Characterisation and Optimisation of Cannabis sativa L. as a Phytopharmaceutical. Ph.D. Dissertation, King's College, London, UK, 2009.

44. Ning, W.; Peng, X.; Ma, L.; Cui, L.; Lu, X.; Wang, J.; Tian, J.; Li, X.; Wang, W.; Zhang, L. Enhanced secondary metabolites production and antioxidant activity in postharvest Lonicera japonica Thunb. in response to UV radiation. Innov. Food Sci. Emerg. Technol. 2012, 13, 231-243. [CrossRef]

45. Schreiner, M.; Mewis, I.; Huyskens-Keil, S.; Jansen, M.A.K.; Zrenner, R.; Winkler, J.B.; O’brien, N.; Krumbein, A. UV-B-induced secondary plant metabolites-potential benefits for plant and human health. CRC. Crit. Rev. Plant Sci. 2012, 31, 229-240. [CrossRef]

46. Pate, D.W. Chemical ecology of Cannabis. J. Int. Hemp Assoc. 1994, 2, 32-37.

47. Heath, R.L.; Packer, L. Photoperoxidation in isolated chloroplasts: I. Kinetics and stoichiometry of fatty acid peroxidation. Arch. Biochem. Biophys. 1968, 125, 189-198. [CrossRef]

48. Singh, N.; Ma, L.Q.; Srivastava, M.; Rathinasabapathi, B. Metabolic adaptations to arsenic-induced oxidative stress in Pteris vittata L. and Pteris ensiformis L. Plant Sci. 2006, 170, 274-282. [CrossRef]

49. Islam, M.J.; Ryu, B.R.; Azad, M.O.K.; Rahman, M.H.; Rana, M.S.; Lim, J.-D.; Lim, Y.-S. Exogenous Putrescine Enhances Salt Tolerance and Ginsenosides Content in Korean Ginseng (Panax ginseng Meyer) Sprouts. Plants 2021, 10, 1313. [CrossRef]

50. Islam, M.J.; Kim, J.W.; Begum, M.K.; Sohel, M.A.T.; Lim, Y.-S. Physiological and Biochemical Changes in Sugar Beet Seedlings to Confer Stress Adaptability under Drought Condition. Plants 2020, 9, 1511. [CrossRef] [PubMed]

51. Giannopolitis, C.N.; Ries, S.K. Superoxide dismutases: I. Occurrence in higher plants. Plant Physiol. 1977, 59, 309-314. [CrossRef]

52. Zhang, X.Z. The measurement and mechanism of lipid peroxidation and SOD, POD and CAT activities in biological system. Res. Methodol. Crop Physiol. Agric. Press. Beijing 1992, 15, 208-211.

53. Nakano, Y.; Asada, K. Hydrogen peroxide is scavenged by ascorbate-specific peroxidase in spinach chloroplasts. Plant Cell Physiol. 1981, 22, 867-880.

54. Singleton, V.L.; Rossi, J.A. Colorimetry of total phenolics with phosphomolybdic-phosphotungstic acid reagents. Am. J. Enol. Vitic. 1965, 16, 144-158.

55. Ghimeray, A.K.; Sharma, P.; Phoutaxay, P.; Salitxay, T.; Woo, S.H.; Park, S.U.; Park, C.H. Far infrared irradiation alters total polyphenol, total flavonoid, antioxidant property and quercetin production in tartary buckwheat sprout powder. J. Cereal Sci. 2014, 59, 167-172. [CrossRef]

56. Braca, A.; Fico, G.; Morelli, I.; De Simone, F.; Tomè, F.; De Tommasi, N. Antioxidant and free radical scavenging activity of flavonol glycosides from different Aconitum species. J. Ethnopharmacol. 2003, 86, 63-67. [CrossRef]

57. Xia, J.; Psychogios, N.; Young, N.; Wishart, D.S. MetaboAnalyst: A web server for metabolomic data analysis and interpretation. Nucleic Acids Res. 2009, 37, W652-W660. [CrossRef]

58. Ye, S.; Shao, Q.; Xu, M.; Li, S.; Wu, M.; Tan, X.; Su, L. Effects of light quality on morphology, enzyme activities, and bioactive compound contents in Anoectochilus roxburghii. Front. Plant Sci. 2017, 8, 857. [CrossRef] [PubMed]

59. Wang, N.; Gao, J.; Zhang, S. Overcompensation or limitation to photosynthesis and root hydraulic conductance altered by rehydration in seedlings of sorghum and maize. Crop J. 2017, 5, 337-344. [CrossRef]

60. Xiong, D.; Douthe, C.; Flexas, J. Differential coordination of stomatal conductance, mesophyll conductance, and leaf hydraulic conductance in response to changing light across species. Plant Cell Environ. 2018, 41, 436-450. [CrossRef] [PubMed]

61. Yi, Z.; Cui, J.; Fu, Y.; Liu, H. Effect of different light intensity on physiology, antioxidant capacity and photosynthetic characteristics on wheat seedlings under high $\mathrm{CO}_{2}$ concentration in a closed artificial ecosystem. Photosynth. Res. 2020, 144, 23-34. [CrossRef]

62. Kura-Hotta, M.; Satoh, K.; Katoh, S. Relationship between photosynthesis and chlorophyll content during leaf senescence of rice seedlings. Plant Cell Physiol. 1987, 28, 1321-1329. 
63. Spano, G.; Di Fonzo, N.; Perrotta, C.; Platani, C.; Ronga, G.; Lawlor, D.W.; Napier, J.A.; Shewry, P.R. Physiological characterization of 'stay green'mutants in durum wheat. J. Exp. Bot. 2003, 54, 1415-1420. [CrossRef] [PubMed]

64. Choudhury, S.; Panda, P.; Sahoo, L.; Panda, S.K. Reactive oxygen species signaling in plants under abiotic stress. Plant Signal. Behav. 2013, 8, e23681. [CrossRef]

65. Tripathy, B.C.; Oelmüller, R. Reactive oxygen species generation and signaling in plants. Plant Signal. Behav. 2012, 7, 1621-1633. [CrossRef]

66. Khan, M.I.R.; Khan, N.A. Reactive Oxygen Species and Antioxidant Systems in Plants: Role and Regulation under Abiotic Stress; Springer: Berlin/Heidelberg, Germany, 2017; ISBN 9811052549.

67. Pospíšil, P. Production of reactive oxygen species by photosystem II as a response to light and temperature stress. Front. Plant Sci. 2016, 7, 1950. [CrossRef]

68. Heber, U. Irrungen, Wirrungen? The Mehler reaction in relation to cyclic electron transport in C3 plants. In Discoveries in Photosynthesis; Beatty, J.T., Gest, H., Allen, J.F., Eds.; Springer: Berlin/Heidelberg, Germany, 2005; pp. 551-559.

69. Das, K.; Roychoudhury, A. Reactive oxygen species (ROS) and response of antioxidants as ROS-scavengers during environmental stress in plants. Front. Environ. Sci. 2014, 2, 53. [CrossRef]

70. Karuppanapandian, T.; Moon, J.-C.; Kim, C.; Manoharan, K.; Kim, W. Reactive oxygen species in plants: Their generation, signal transduction, and scavenging mechanisms. Aust. J. Crop Sci. 2011, 5, 709.

71. Navrot, N.; Rouhier, N.; Gelhaye, E.; Jacquot, J. Reactive oxygen species generation and antioxidant systems in plant mitochondria. Physiol. Plant. 2007, 129, 185-195. [CrossRef]

72. Luis, A.; Sandalio, L.M.; Corpas, F.J.; Palma, J.M.; Barroso, J.B. Reactive oxygen species and reactive nitrogen species in peroxisomes. Production, scavenging, and role in cell signaling. Plant Physiol. 2006, 141, 330-335.

73. Palma, J.M.; Corpas, F.J.; del Rio, L.A. Proteome of plant peroxisomes: New perspectives on the role of these organelles in cell biology. Proteomics 2009, 9, 2301-2312. [CrossRef]

74. Ahmad, P.; Jaleel, C.A.; Salem, M.A.; Nabi, G.; Sharma, S. Roles of enzymatic and nonenzymatic antioxidants in plants during abiotic stress. Crit. Rev. Biotechnol. 2010, 30, 161-175. [CrossRef] [PubMed]

75. Huang, H.; Ullah, F.; Zhou, D.-X.; Yi, M.; Zhao, Y. Mechanisms of ROS regulation of plant development and stress responses. Front. Plant Sci. 2019, 10, 800. [CrossRef] [PubMed]

76. Xie, X.; He, Z.; Chen, N.; Tang, Z.; Wang, Q.; Cai, Y. The roles of environmental factors in regulation of oxidative stress in plant. BioMed Res. Int. 2019, 2019, 9732325. [CrossRef]

77. Gaschler, M.M.; Stockwell, B.R. Lipid peroxidation in cell death. Biochem. Biophys. Res. Commun. 2017, 482, 419-425. [CrossRef]

78. Catalá, A.; Díaz, M. Impact of lipid peroxidation on the physiology and pathophysiology of cell membranes. Front. Physiol. 2016, 7, 423. [CrossRef] [PubMed]

79. Repetto, M.; Semprine, J.; Boveris, A. Lipid Peroxidation: Chemical Mechanism, Biological Implications and Analytical Determination. In Lipid Peroxidation; IntechOpen: London, UK, 2012; Chapter 1. [CrossRef]

80. Sharma, P.; Jha, A.B.; Dubey, R.S.; Pessarakli, M. Reactive oxygen species, oxidative damage, and antioxidative defense mechanism in plants under stressful conditions. J. Bot. 2012, 2012, 217037. [CrossRef]

81. Wu, H. Effect of different light qualities on growth, pigment content, chlorophyll fluorescence, and antioxidant enzyme activity in the red alga Pyropia haitanensis (Bangiales, Rhodophyta). Biomed Res. Int. 2016, 2016, 7383918. [CrossRef]

82. DaCosta, M.; Huang, B. Changes in antioxidant enzyme activities and lipid peroxidation for bentgrass species in response to drought stress. J. Am. Soc. Hortic. Sci. 2007, 132, 319-326. [CrossRef]

83. Alam, M.M.; Nahar, K.; Hasanuzzaman, M.; Fujita, M. Exogenous jasmonic acid modulates the physiology, antioxidant defense and glyoxalase systems in imparting drought stress tolerance in different Brassica species. Plant Biotechnol. Rep. 2014, 8, $279-293$. [CrossRef]

84. Qamaruddin, M.; Tillberg, E. Rapid effects of red light on the isopentenyladenosine content in Scots pine seeds. Plant Physiol. 1989, 91, 5-8. [CrossRef]

85. Lee, S.-C.; Kim, J.-H.; Jeong, S.-M.; Kim, D.-R.; Ha, J.-U.; Nam, K.C.; Ahn, D.U. Effect of far-infrared radiation on the antioxidant activity of rice hulls. J. Agric. Food Chem. 2003, 51, 4400-4403. [CrossRef] [PubMed]

86. Brazaityte, A.; Virsile, A.; Jankauskiene, J.; Sakalauskiene, S.; Samuoliene, G.; Sirtautas, R.; Novickovas, A.; Dabasinskas, L.; Miliauskiene, J.; Vastakaite, V. Effect of supplemental UV-A irradiation in solid-state lighting on the growth and phytochemical content of microgreens. Int. Agrophys. 2015, 29, 13-22. [CrossRef]

87. Długosz-Grochowska, O.; Wojciechowska, R.; Kruczek, M.; Habela, A. Supplemental lighting with LEDs improves the biochemical composition of two Valerianella locusta (L.) cultivars. Hortic. Environ. Biotechnol. 2017, 58, 441-449. [CrossRef]

88. Vaštakaitè, V.; Viršilè, A.; Brazaitytè, A.; Samuolienè, G.; Jankauskienė, J.; Sirtautas, R.; Novičkovas, A.; Dabašinskas, L.; Sakalauskienè, S.; Miliauskienè, J. The effect of blue light dosage on growth and antioxidant properties of microgreens. Sodininkyste Daržininkystè 2015, 34, 25-35.

89. Park, S.U.; Ahn, D.-J.; Jeon, H.-J.; Kwon, T.R.; Lim, H.-S.; Choi, B.-S.; Baek, K.-H.; Bae, H. Increase in the contents of ginsenosides in raw ginseng roots in response to exposure to 450 and $470 \mathrm{~nm}$ light from light-emitting diodes. J. Ginseng Res. 2012, 36, 198. [CrossRef]

90. Eom, S.H.; Park, H.J.; Seo, D.W.; Kim, W.W.; Cho, D.H. Stimulating effects of far-infrared ray radiation on the release of antioxidative phenolics in grape berries. Food Sci. Biotechnol. 2009, 18, 362-366. 
91. Fellermeier, M.; Zenk, M.H. Prenylation of olivetolate by a hemp transferase yields cannabigerolic acid, the precursor of tetrahydrocannabinol. FEBS Lett. 1998, 427, 283-285. [CrossRef]

92. Degenhardt, F.; Stehle, F.; Kayser, O. The biosynthesis of cannabinoids. In Handbook of Cannabis and Related Pathologies; Preedy, V.R., Ed.; Elsevier: Amsterdam, The Netherlands, 2017; pp. 13-23.

93. Taura, F.; Morimoto, S.; Shoyama, Y.; Mechoulam, R. First direct evidence for the mechanism of. DELTA. 1-tetrahydrocannabinolic acid biosynthesis. J. Am. Chem. Soc. 1995, 117, 9766-9767. [CrossRef]

94. Sirikantaramas, S.; Taura, F.; Tanaka, Y.; Ishikawa, Y.; Morimoto, S.; Shoyama, Y. Tetrahydrocannabinolic acid synthase, the enzyme controlling marijuana psychoactivity, is secreted into the storage cavity of the glandular trichomes. Plant Cell Physiol. 2005, 46, 1578-1582. [CrossRef] [PubMed]

95. De Backer, B.; Maebe, K.; Verstraete, A.G.; Charlier, C. Evolution of the content of THC and other major cannabinoids in drug-type cannabis cuttings and seedlings during growth of plants. J. Forensic Sci. 2012, 57, 918-922. [CrossRef] [PubMed]

96. Sirikantaramas, S.; Morimoto, S.; Shoyama, Y.; Ishikawa, Y.; Wada, Y.; Shoyama, Y.; Taura, F. The gene controlling marijuana psychoactivity molecular cloning and heterologous expression of $\Delta 1$-tetrahydrocannabinolic acid synthase from Cannabis sativa $\mathrm{L}$. J. Biol. Chem. 2004, 279, 39767-39774. [CrossRef] [PubMed]

97. Chandra, S.; Lata, H.; Khan, I.A.; Elsohly, M.A. Photosynthetic response of Cannabis sativa L. to variations in photosynthetic photon flux densities, temperature and $\mathrm{CO}_{2}$ conditions. Physiol. Mol. Biol. Plants 2008, 14, 299-306. [CrossRef] [PubMed]

98. Magagnini, G.; Grassi, G.; Kotiranta, S. The Effect of Light Spectrum on the Morphology and Cannabinoid Content of Cannabis sativa L. Med. Cannabis Cannabinoids 2018, 1, 19-27. [CrossRef]

99. Mahlberg, P.G.; Hemphill, J.K. Effect of light quality on cannabinoid content of Cannabis sativa L.(Cannabaceae). Bot. Gaz. 1983, 144, 43-48. [CrossRef]

100. Caplan, D.; Dixon, M.; Zheng, Y. Increasing inflorescence dry weight and cannabinoid content in medical cannabis using controlled drought stress. HortScience 2019, 54, 964-969. [CrossRef]

101. Taghinasab, M.; Jabaji, S. Cannabis Microbiome and the Role of Endophytes in Modulating the Production of Secondary Metabolites: An Overview. Microorganisms 2020, 8, 355. [CrossRef] [PubMed]

102. Hampson, A.J.; Grimaldi, M.; Lolic, M.; Wink, D.; Rosenthal, R.; Axelrod, J. Neuroprotective antioxidants from marijuana. Ann. New York Acad. Sci. 2000, 899, 274-282. [CrossRef]

103. Shoyama, Y.; Sugawa, C.; Tanaka, H.; Morimoto, S. Cannabinoids act as necrosis-inducing factors in Cannabis sativa. Plant Signal. Behav. 2008, 3, 1111-1112. [CrossRef] 